\title{
Mineralogical and geochemical evidence of magma mingling/mixing in the Sierra de las Cruces volcanic range, Mexican Volcanic Belt
}

\author{
Evidencias mineralógicas y geoquímicas de mezcla incompleta de \\ magmas en la Sierra de las Cruces, Cinturón Volcánico Mexicano
}

\author{
F. Velasco-Tapia ${ }^{1 *}$, P. Rodríguez-Saavedra ${ }^{1}$, A. Márquez ${ }^{2}$, I. Navarro de León ${ }^{1}$, C. De Ignacio ${ }^{3}$, S. \\ G. Marroquín Guerra ${ }^{4}$, J. Quintanilla-Garza ${ }^{5}$, O.M. Rangel-Álvarez ${ }^{1}$ \\ ${ }^{1}$ Universidad Autónoma de Nuevo León, UANL, Facultad de Ciencias de la Tierra, Av. Universidad S/N, \\ Ciudad Universitaria, 66451 San Nicolás de los Garza, Nuevo León, México.velasco@fct.uanl.mx; \\ saavedra@fct.uanl.mx; inavarro23@fct.uanl.mx. \\ ${ }^{2}$ Grupo de Geología, Escuela Superior de C.C. Experimentales y Tecnología, Universidad Rey Juan \\ Carlos, c/Tulipans/n, Móstoles, 28933 Madrid,Spain.alvaro.marquez@urjc.es \\ ${ }^{3}$ Departamento de Petrología y Geoquímica, Facultad de Ciencias Geológicas, Universidad Complutense, \\ Cd. Universitaria, c/José Antonio Novais No. 2, 28040 Madrid,Spain.cris@geo.ucm.es \\ ${ }^{4}$ Universidad Autónoma de Nuevo León, UANL, Escuela Preparatoria No. 4, Av. Universidad S/N, Ciudad \\ Universitaria, 66451 San Nicolás de los Garza, Nuevo León, México.sylvia.marroquing@uanl.mx \\ ${ }^{5}$ First Majestic - Silver Corp. Unidad San Martin de Bolaños. c/ Fanny Anitua No. 2700, Col. Los \\ Ángeles, 34076 Durango, Durango, México.jquintanilla@firstmajestic.com \\ *corresponding author:velasco@fct.uanl.mx
}

Received: 19/05/2011 / Accepted: 12/04/2013

\begin{abstract}
Pliocene - Pleistocene lava flows, mainly of dacitic composition, are exposed in the Sierra de las Cruces (SC) volcanic range within the Mexican Volcanic Belt (MVB).

$\mathrm{SC}$ volcanic rocks are porphyritic, generally containing an assemblage of plagioclase + amphibole + orthopyroxene \pm clinopyroxene \pm quartz $\pm \mathrm{Fe}$-Ti oxides. Most of them exhibit diverse mineralogical and geochemical features that attest a magma mixing and mingling processes with concomitant fractional crystallization in which a small volume of hot andesite magma injects into dacitic magma. Both rock types are probably derived from partial melting of continental crust at different levels.

The evidences of magma mixing and mingling include: (a) normal and sieved plagioclases in the same sample, rounded and embayed crystals, and armoured rims over the dissolved crystal surfaces; (b) subrounded, vesicular magmatic enclaves, ranging from a few millimeters to $\sim 20$ centimeters in size, with plagioclase + orthopyroxene + amphibole + quartz \pm olivine \pm Fe-Ti-oxides assemblage; (c) mineral chemistry evidence such as crystals with reaction rims or heterogeneous plagioclase compositions (inverse and oscillatory zoning or normally and inversely zoned crystals) in the same sample; and (d) elemental geochemical variations and trace-element ratio more akin to magma mixing and to some extent diffusion process.

These andesitic enclaves could be considered as portions of the intermediate magma that did not mix completely (mingling) with the felsic host lavas, confirming the major role of magma mixing and mingling processes in the overall evolution of the MVB
\end{abstract}


Keywords: Magma mixing, mingling, chilled magmatic enclaves, mineralogical disequilibrium, Las Cruces volcanic range, Mexican Volcanic Belt, Mexico.

\section{Resumen}

En la Sierra de las Cruces (SC), Cinturón Volcánico Mexicano (CVM), se encuentran expuestos flujos de lava, principalmente de composición dacítica, del Plioceno-Pleistoceno.

Las rocas volcánicas de la SC son de textura porfirítica, conteniendo plagioclasa + anfibol + ortopiroxeno \pm clinopiroxeno \pm cuarzo \pm óxidos de Fe-Ti. La mayor parte de ellas exhiben diversas características que indican un proceso de mezcla incompleta de magmas, con una cristalización fraccionada concomitante, en la que un pequeño volumen de un magma andesítico caliente es inyectado a un magma dacítico. Es probable que ambos tipos de roca se hayan generado por fusión parcial a diferentes niveles de la corteza continental.

Las evidencias de la mezcla incompleta de magmas incluyen: (a) plagioclasas con texturas normal y anubarrada en la misma muestra, cristales redondeados y corroídos, y bordes de reacción en superficies de cristal disueltas; (b) enclaves magmáticos subredondeados y vesiculares, que ocurren en dimensiones de un pocos milímetros a 20 centímetros de diámetro, con plagioclasa + ortopiroxeno + anfíbol + cuarzo \pm olivino \pm óxidos de Fe-Ti; (c) química de minerales, que incluye cristales con bordes de reacción o plagioclasas de composición heterogénea (zonación inversa y oscilatoria o cristales con zonación normal e inversa) en la misma muestra; y (d) variaciones geoquímicas de elementos y relaciones de elementos traza explicables por una mezcla de magmas y por un proceso de difusión.

Los enclaves andesíticos podrían considerarse como porciones de magma intermedio que no se mezcló con los líquidos dacíticos receptores, lo que confirma la importancia de los procesos de mezcla incompleta de magmas en la evolución magmática del CVM.

Palabras clave: Mezcla de magmas, mezcla incompleta, enclaves magmáticos, desequilibrio mineralógico, sierra volcánica Las Cruces, Cinturón Volcánico Mexicano, México.

\section{Introduction}

The Mexican Volcanic Belt (MVB; Fig. 1) is a geologic province of $\sim 8000$ volcanic centers (stratovolcanoes, cinder cones, maars, etc.) of Miocene to present-day, predominantly having an andesitic to dacitic composition. The MVB is $\sim 1000 \mathrm{~km}$ long and $50-300 \mathrm{~km}$ wide, extending approximately east-west from Veracruz to Puerto Vallarta (Gómez-Tuena et al., 2007). The MVB origin has generally been viewed as related to the subduction of the Cocos and Rivera plates subduction beneath the North American plate (Pardo and Suárez, 1995; Ferrari et al., 1999). However, some geological, geochemical and geophysical observations do not completely agree with a unique subduction-related origin for the MVB, as summarized by Márquez et al. (1999a,b) and Sheth et al. (2000). Alternative models have been proposed to explain the MVB origin and these include: (a) hybrid models involving both mantle and slab sources (Luhr, 1997; Wallace and Carmichael, 1999; Ferrari, 2004); (b) the activity of a west-east propagating mantle plume coexisting with the subduction of the Cocos and Rivera plates (Márquez et al., 1999a); and (c) the ongoing extensional processes along the MVB (Sheth et al., 2000; Verma, 2002, 2009).

On the other hand, several geochemical and isotopic studies reveal the crust participation in the genesis of the MVB intermediate and silica-rich magmas. Besch et al. (1995) determined that an assimilation of lower crust can explain the chemical and isotopic differences between primitive mafic and evolved rocks in the eastern MVB.
Verma (1999) reported that andesites and dacites from the Sierra de Chichinautzin volcanic field (central MVB) were derived from partial melting of a heterogeneous mafic granulite from the lower crust. Later, Márquez and De Ignacio (2002) suggested that the magmatic diversity of Sierra de Chichinautzin can be explained by magma mixing between mafic magmas derived from a heterogeneous upper mantle and two different felsic crustal magmas. Chelsey et al. (2002), based on geochemical and isotopic data (particularly Os isotopic ratios), reported that the Michoacan-Guanajuato volcanism (central MVB) shows assimilation of the lower crust. Magma mixing processes, between magmas of different composition, have also been inferred from the phenocryst assemblages and geochemistry of the Iztaccíhuatl (Nixon, 1988a,b),Tequila (Wallace and Carmichael, 1994), Tancítaro (Ownby et al., 2011), and Popocatépetl volcanoes (Straub and Martin-Del Pozzo, 2001; Schaaf et al., 2005; Witter et al., 2005; Sosa-Ceballos et al., 2012), as well as in Amealco caldera (Aguirre-Díaz, 2001).

Therefore, it is clear that detailed studies involving mineralogical, geochemical, and isotopic data are required to explain the magmatic diversity observed in the MVB and to try to solve the controversies related to this significant geologic province. This paper describes an initial petrogenetic evaluation of magmatism in the Sierra de las Cruces (SC) volcanic range, based on mineralogi$\mathrm{cal}$, geochemical, and $\mathrm{Sr}-\mathrm{Nd}$ isotopic ratios of intermediate and felsic volcanic rocks. The lithological features of SC volcanic range represent an opportunity to test the 


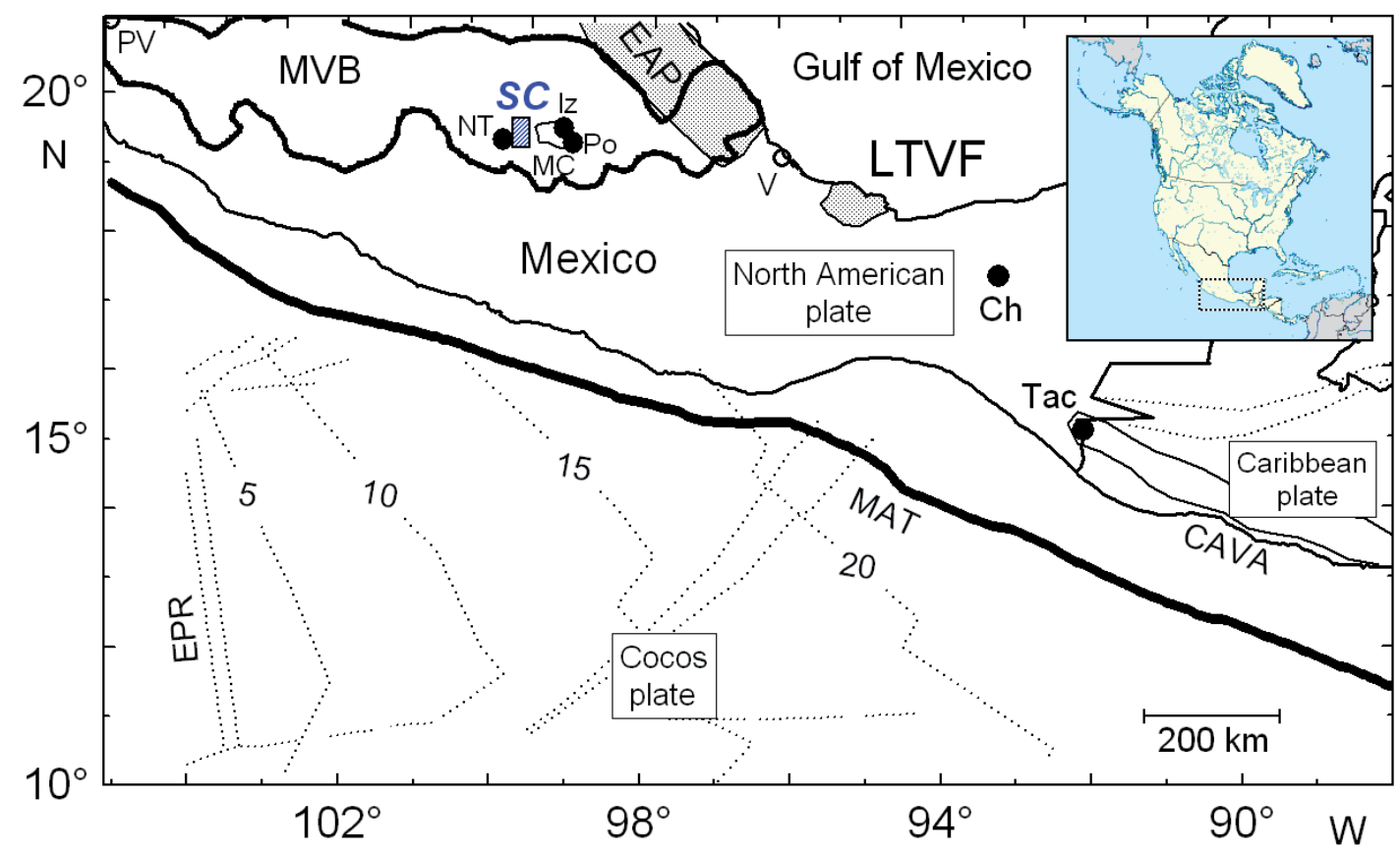

Fig. 1.- Location of Miocene to present-day volcanism in the Mexican Volcanic Belt (MVB), Los Tuxtlas volcanic field (LTVF), part of the Eastern Alkaline province (EAP) and the Central American Volcanic Arc (CAVA). For guidance, the black box at the upper right side shows the location of this zone in North America. Blue shaded box indicates the Sierra de las Cruces (SC) volcanic range. Main stratovolcanoes surrounding the SC: NT $=$ Nevado de Toluca, Iz = Iztaccíhuatl, and Po = Popocatépetl. The plate tectonic relationship of the subducting Cocos plate with the North American and Caribbean plates is also shown. The curves marked 5, 10, 15, and 20 show the approximate age of the ocean crust in Ma. MAT = Middle American Trench, $\mathrm{EPR}=$ East Pacific Rise, $\mathrm{Ch}=\mathrm{El}$ Chichón volcano, Tac $=$ Tacaná volcano; $\mathrm{MC}=$ Mexico City, $\mathrm{V}=\mathrm{Veracruz}, \mathrm{PV}=\mathrm{Puerto}$ Vallarta (modified from Verma, 2002).

Fig. 1.- Ubicación del vulcanismo desde el Mioceno a la actualidad en el Cinturón Volcánico Mexicano (MVB), el campo volcánico Los Tuxtlas (LTVF), una parte de la Provincia Alcalina Oriental (EAP) y el Arco Volcánico de Centroamérica (CAVA). Para orientación, el recuadro en negro en la parte superior derecha muestra la ubicación de esta zona en Norteamérica. El recuadro sombreado en azul indica la ubicación de la Sierra de las Cruces (SC). Principales estratovolcanes que rodean a la SC: NT = Nevado de Toluca, Iz = Iztaccíhuatl, and Po = Popocatépetl. También se presenta la relación tectónica de la placa de subducción Cocos con las de Norteamérica y Caribe. Las curvas marcadas con 5, 10, 15 y 20 muestran la edad aproximada de la corteza oceánica en Ma. MAT $=$ Trinchera Mesoamericana, EPR $=$ Cresta del Pacífico Oriental, Ch $=$ volcán El Chichón, Tac $=$ volcán Tacaná; $\mathrm{MC}=$ Ciudad de México, V = Veracruz, PV = Puerto Vallarta (modificado de Verma, 2002).

role of the continental crust in the origin and evolution of magmas in the central MVB.

\section{Geological setting}

\subsection{Regional stratigraphy}

Vázquez-Sánchez and Jaimes-Palomera (1989) and García-Palomo et al. (2002) have reported detailed stratigraphic information for the SC surrounding regions (Mexico and Toluca basins), covering the Cretaceous to present-day period. Stratigraphic record begins with a calcareous sedimentary sequence (marine to shelf facies) that was deposited in central Mexico during the Cretaceous (Fries, 1960). Rocks from this sequence include massive limestone with black chert lenses, beds of gypsum, massive to thickly bedded limestones, greywacke interbedded with limolite and shale beds. This Cretaceous sedimentary sequence (thickness $\sim 3000 \mathrm{~m}$ ) was folded and uplifted during the Laramide orogenic event (Fries, 1960) and was subsequently intruded by granitic or granodioritic dykes dated at $50 \pm 10 \mathrm{Ma}$ (De Cserna et al. 1974). The EoceneOligocene stratigraphy that overlies the Cretaceous sequence consists of calcareous conglomerates, lava flows, sandstones, volcanic siltstones, and lacustrine deposits, with a maximum thickness of $500 \mathrm{~m}$.

This sedimentary sequence is unconformably overlain by about 38 to $7.5 \mathrm{Ma}$ rhyolite, rhyodacite, dacitic lava flows and pyroclastic flow deposits (Morán-Zenteno et al. 1998; García-Palomo et al. 2002), and by a Pliocene to Holocene volcanism of the MVB, that include the Las Cruces eruptive period (Delgado-Granados and Martin del Pozzo 1993).

\subsection{Central MVB Pliocene to Holocene volcanism}

The Pliocene to Holocene volcanism in the central MVB was generated during three eruptive periods (Delgado-Granados and Martin del Pozzo, 1993): Las Cruces, Ajusco, and Chichinautzin. 


\section{Las Cruces eruptive period}

It is considered as the oldest one, from Late Pliocene to Early Pleistocene (Fries, 1960; Schaelpfer, 1968; Sánchez-Rubio, 1984; Delgado-Granados and Martin del Pozzo, 1993). Mora-Alvarez et al. (1991) reported K-Ar dates from 2.87 to $1.92 \mathrm{Ma}$ for this volcanism, whereas Osete et al. (2000), combining magnetostratigraphic and $\mathrm{K}$-Ar radiometric data, established that this eruptive period can be best constrained between 3.6 and $1.8 \mathrm{Ma}$. The main mass of SC range (Fig. 2) was formed by consecutive episodes of faulting accompanied by the development of volcanic edifices, constructed by lavas and associated pyroclastic products (Mooser et al., 1974; Fries, 1960; Schlaepfer, 1968; Delgado-Granados and Martin del Pozzo, 1993; García-Palomo et al., 2002, 2008). The volcanic range is elongated, extending in a NNW-SSE direction for $\sim 65 \mathrm{~km}$, with a width varying from $47 \mathrm{~km}$ to the north and $27 \mathrm{~km}$ to the south. The SC constitutes the western margin of the Mexico basin (2220 m.a.s.1.) and the eastern border of the Toluca Valley (2400 m.a.s.1.), both being graben/horst depressions. According to García Palomo et al. (2008), the SC volcanic field has been divided in three sectors: northern, central, and southern, all of them bounded by E-W faults. Each sector is characterized by specific altitudes, slopes, trends of morpholineaments, and drainage patterns. Morphostructure of the northern and central sectors is controlled by N-S and NE-SW faults, whereas E-W faults have ruled the southern sector. An N-S spatial-temporal evolution of SC magmatic activity was confirmed by paleomagnetic and $\mathrm{K}-\mathrm{Ar}$ data (Mora Alvarez et al., 1991; Osete et al., 2000; Fig. 2). The SC consists of eight overlapped stratovolcanoes, which are named, from south to north: Zempoala, La Corona, San Miguel, Salazar, Chimalpa, Iturbide, La Bufa, and La Catedral (García-Palomo et al., 2008). These volcanic edifices underwent alternated episodes of effusive and explosive activity, during which they were affected by faulting. Effusive products comprise gray andesitic to dacitic porphyritic lava flows $(<4 \mathrm{~m}$ thick) with planar fracturing sub parallel to the surface, labeled as Lava Dacítica Apilulco (total thickness $\sim 400 \mathrm{~m}$ ) by DelgadoGranados and Martin del Pozzo (1993). Occasionally, these lava flows contain magmatic enclaves (see Table 1 in Appendix A), which are dark gray on fresh surfaces and may appear lighter than the host on weathered surfaces. The enclaves comprise $<2$ to 10 vol $\%$ of the rock at a given outcrop. Their shape is commonly spherical to ellipsoidal and only rarely angular on 2D outcrop, with a finely crystalline and vesicular texture in hand specimen. They are randomly distributed over the volcanic range, although their number and size apparently increase towards the north. This fact could be related to an increase in fault and fracture density in this direction (García-Palomo et al., 2008), a favorable condition for magma mingling/mixing processes. The most common enclaves are small, ranging from a few millimeters to 4 centimeters in diameter, although in the northern sector they can reach a maximum dimension of $\sim 20$ centimeters. Enclave contacts with their host dacite are generally sharp and crenulated, showing chilled margins. Their morphology and vesicularity of the ME indicate that they were partially molten before they were entrained into and quenched against relatively cooler host dacitic melt. On the other hand, lava flows are sometimes intercalated by pyroclastic deposits (Brecha Piroclástica Cantimplora after Delgado-Granados and Martin del Pozzo, 1983; total thickness $=1-4 \mathrm{~m})$ conformed by gray dacitic blocks $(20-30$ $\mathrm{cm})$, pumice clasts $(<15 \mathrm{~cm})$, and ashes.

\section{Ajusco eruptive period}

During this event, in the Middle Pleistocene, the Ajusco volcano was formed by the extrusion of several andesitic domes. Mora Alvarez et al. (1991) reported a K-Ar age of $0.39 \pm 0.15 \mathrm{Ma}$ for a sample from the Ajusco southern flank.

\section{Chichinautzin eruptive period}

This last eruptive stage was characterized by monogenetic activity generating scoria cones with associated lava flows and shield volcanoes. ${ }^{14} \mathrm{C}$ dating yields ages $<40,000$ years for the Chichinautzin eruption products (Márquez et al., 1999b; Wallace and Carmichael, 1999; Velasco-Tapia and Verma, 2001a,b, 2013).

\section{Sampling and analytical techniques}

On the basis of the morphostructural classification by García-Palomo et al. (2008) and geochronological K-Ar data reported by Mora Alvarez et al.(1991) and Osete et al.(2000), we have divided the SC volcanic range in four sectors (Fig. 2): (a) Northern sector (SCN; 2.9 - 3.7 $\mathrm{Ma}$ ); (b) Central sector (SCC; 1.9 - $2.9 \mathrm{Ma}$ ); (c) Southern sector (SCS; 0.7 - 1.9 Ma), and (d) Las Cruces -Chichinautzin transition sector, which includes the Ajusco volcano (SCT; <0.6 Ma). Fifty-two samples were collected across the range, being complemented by eight previously collected ones by Osete et al. (2000; Fig. 2 and Table 1 in Appendix A Supplementary Material).Most of the samples collected correspond to massive lava flows several meters thick, although some dykes and dome structures were also considered. Faulting in the area (e.g., García-Palomo et al., 2008) together with the dense vegetal cover, make difficult to clearly identify which of the proposed stratovolcanoes is the source of the sampled 


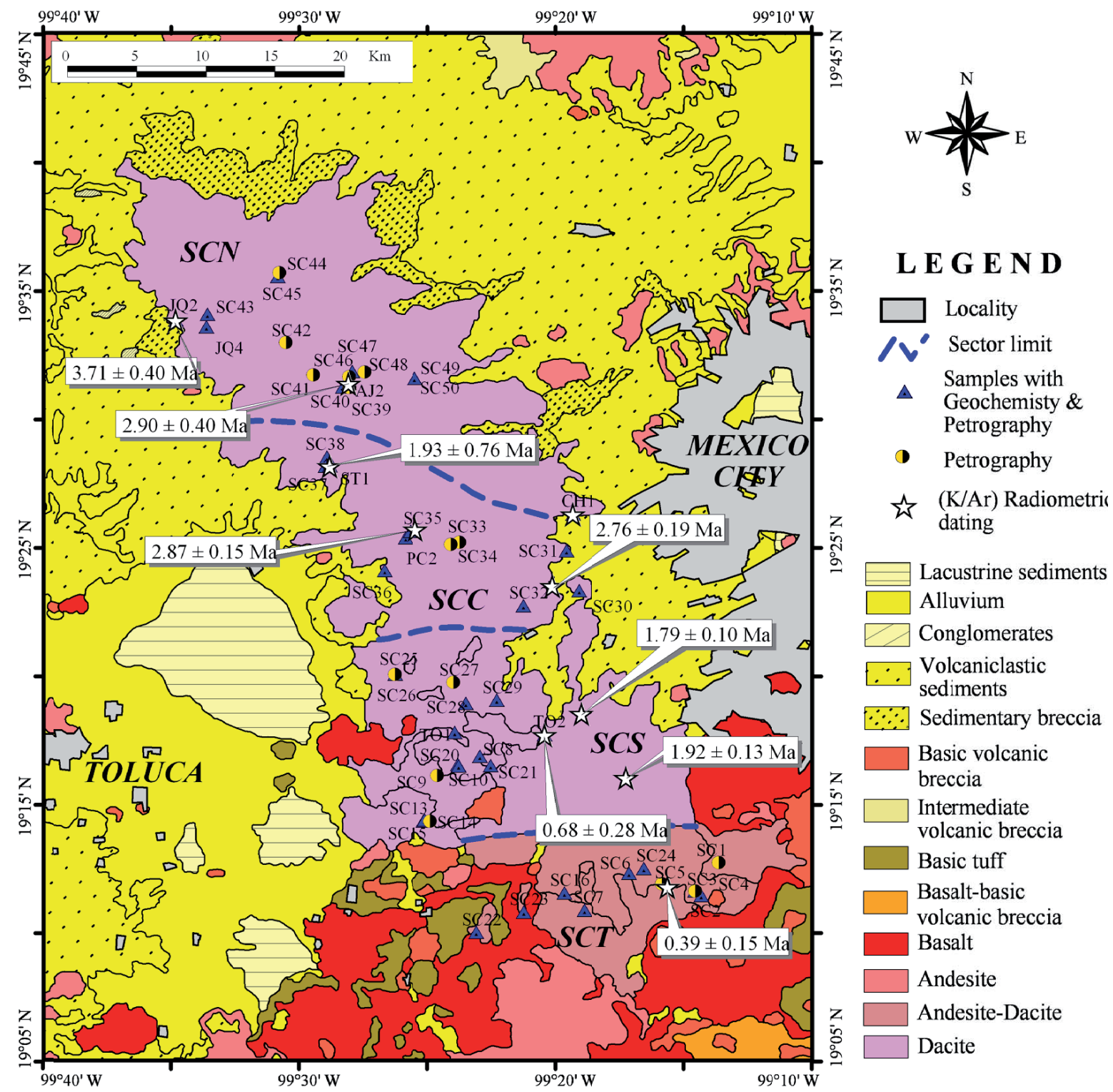

Fig. 2.- Geologic sketch of the Sierra de las Cruces volcanic range, showing lithology, main eruptive centers, and distribution of samples collected along the volcanic range (modified from Instituto Nacional de Estadística, Geografía e Informática (INEGI), 1980, Carta Geológica E14-2 1:250,000).Study area division in four sectors from N to S based on K-Ar radiometric data (stars) reported in the literature (Mora Alvarez et al., 1991; Osete et al., 2000): (a) SCN- northern sector (2.9-3.7 Ma); (b) SCC - central sector (1.9-2.9 Ma); (c) SCS - southern sector (0.7-1.9 Ma), and (d) SCT- transition sector that include the Ajusco volcano $(<0.7 \mathrm{Ma})$.

Fig. 2.- Esquema geológico de la Sierra de las Cruces, mostrando litología, principales centros eruptivos y la distribución de muestras colectadas a lo largo de la sierra volcánica (modificado de Instituto Nacional de Estadística, Geografía e Informática (INEGI), 1980, Carta Geológica E14-2 1:250,000). La división del área de estudio en cuatro sectores de $\mathrm{N}$ a S se basa en datos radiométricos de K-Ar (estrellas) reportados en la literatura (Mora Alvarez et al., 1991; Osete et al., 2000): (a) SCN - sector norte (2.9-3.7 Ma); (b) SCC - sector central (1.9-2.9 Ma); (c) SCS - sector sur (0.7-1.9 Ma) y (d) SCT - sector de transición que incluye el volcán Ajusco $(<0.7 \mathrm{Ma})$.

structures. In seven of the sampled outcrops ellipsoidal magmatic enclaves, up to several centimetres diameter, have been collected in the field.

Modal compositions were determined by point counting on thin sections using a Prior Scientific petrographic microscope. Approximately 500 points per sample were counted in order to obtain a representative mode (Table 1 in Appendix A Supplementary Material). Mineral chemistry was analysed on thin sections of selected sam- ples, using the WDS JXA-8900 JEOL microprobe system of Centro de Microscopía Electrónica, Universidad Complutense (Madrid, Spain). Measurement conditions were $15 \mathrm{kV}$ and $20 \mathrm{nA}$, with a beam diameter of $\sim 1 \mu \mathrm{m}$. The apparent concentrations were corrected for atomic number (Z), absorption (A), and fluorescence (F) effects, automatically applying the internal ZAFJEOL software. Microprobe system calibration was carried out using reference minerals from the Smithsonian Institution (Jarose- 


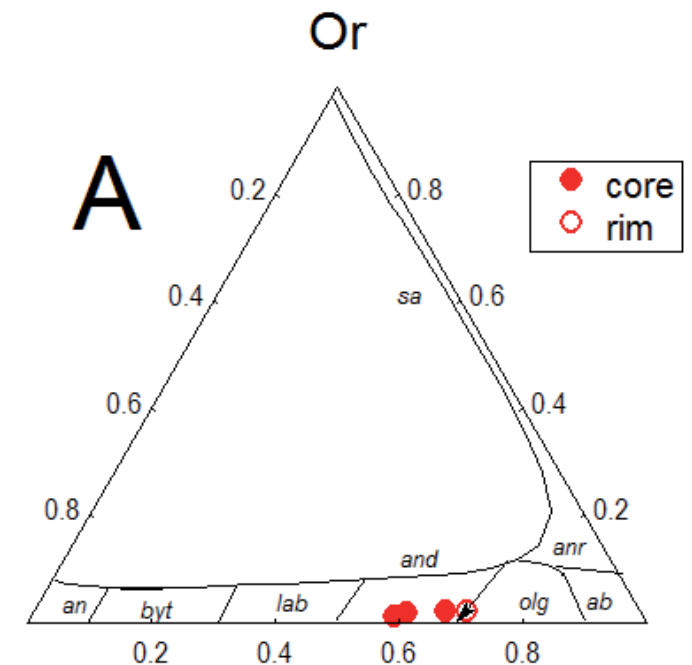

An

$\mathrm{Ab}$

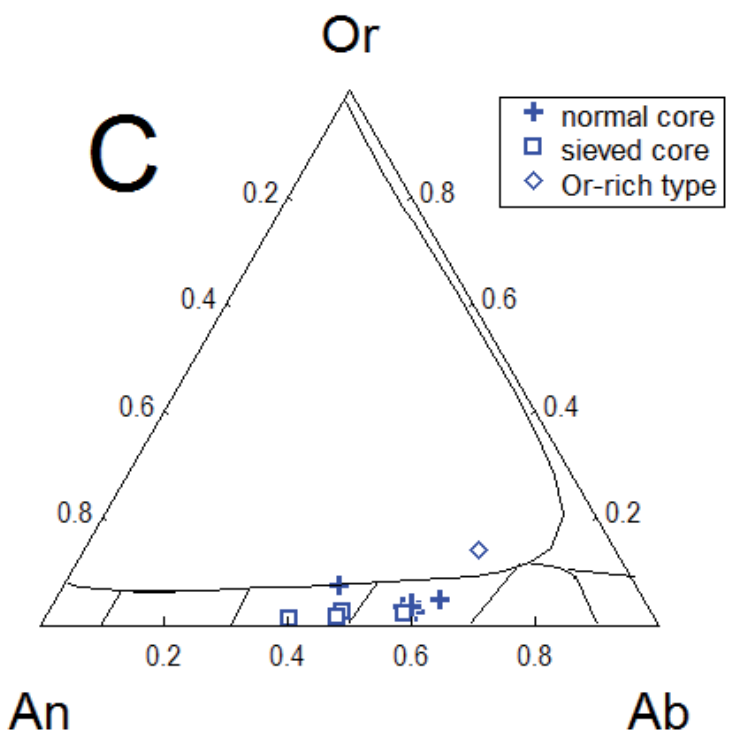

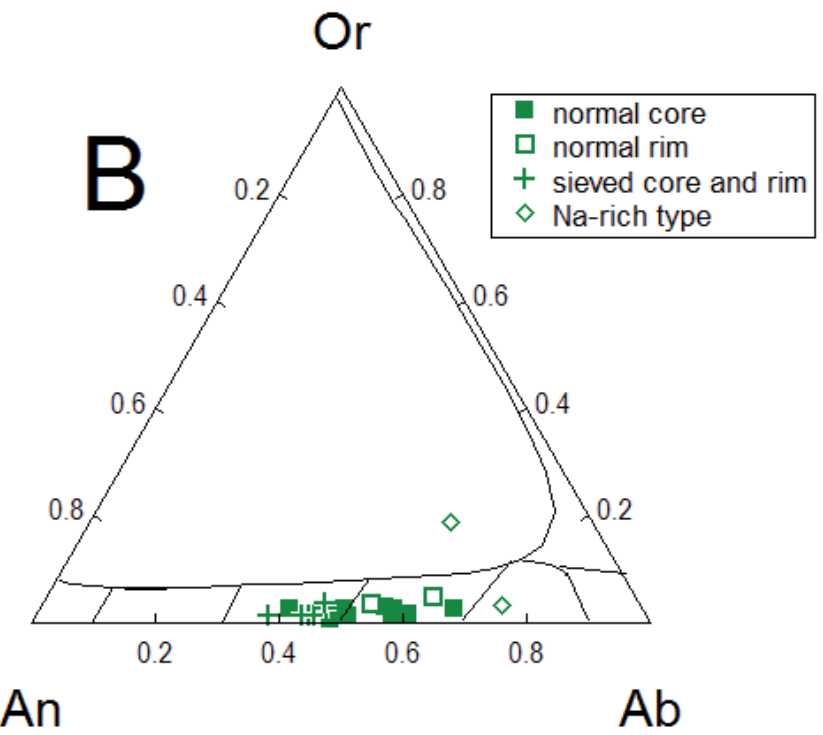

Fig. 3.- Compositional variations of feldspar in SC magmas: (A) F group: felsic magmas, (B) FDE group: felsic magmas with disequilibrium evidence, and (C) $\mathrm{ME}$ group: chilled magmatic enclaves. Location and texture of the feldspar analysis are indicated by symbol shape. Abbreviations: an $=$ anorthite, byt $=$ bytownite, lab = labradorite, and $=$ andesine, olg = oligoclase, $a b=$ albite, or $=$ orthoclase, anr $=$ anorthoclase, $\mathrm{sa}=$ sanidine.

Fig. 3.- Variación composicional de feldespato en los magmas de la SC: (A) Grupo F: magmas félsicos, (B) grupo FDE: magmas félsicos con evidencia de desequilibrio y (C) grupo ME: enclaves magmáticos. La ubicación y textura de los análisis de feldespato se indican por la forma del símbolo. Abreviaturas: an $=$ anortita, byt $=$ bitownita, lab $=$ labradorita, and $=$ andesina, olg $=$ oligoclasa, $a b=$ albita, or $=$ ortoclasa, anr $=$ anorthoclasa, $\mathrm{sa}=$ sanidino. wich et al., 1980). Analytical precision and detection limit data have been reported by Verma et al. (2009). Zoning in different mineral phases was studied by means of profile analysis and scanning probe microanalysis (SEM) images. Amphibole and pyroxene compositions were recalculated for $\mathrm{Fe}^{+3}$ using the charge balance method described by the equation of Droop (1987) equation. Representative analyses of the different mineral types are shown in Tables 2-7 (Appendix A Supplementary Material).

Major and trace element composition of representative SC volcanic rocks (Tables 8 and 9 in Appendix A Supplementary Material) were determined in ActLabs laboratories (Ancaster, Canada), using the "4LithoRes" methodology (for details consult webpage: www.actlabsint. com). Major elements were analyzed by inductively coupled plasma-optical emission spectrometry (ICP-OES) with an analytical precision $<2 \%$ and accuracy typically better than $5 \%$ at $95 \%$ confidence level, based on analysis of diverse geochemical reference materials (GRM).
Trace element concentrations were determined by inductively coupled plasma-mass spectrometry (ICP-MS) with an analytical precision $<10 \%$ and accuracy typically better than $7 \%$ for most elements at the $95 \%$ confidence level, based on analysis of diverse GRM.CIPW norms were calculated on a100\% anhydrous adjusted basis of major elements, with $\mathrm{Fe}_{2} \mathrm{O}_{3} / \mathrm{FeO}$ ratios adjusted depending on the rock type (Middlemost, 1989). Rock classification was based on the total alkali-silica (TAS) scheme (LeBas et al., 1986; LeBas, 1989). All computations (anhydrous and iron-oxidation ratio adjustments, norm compositions, and rock classifications) were automatically done using the SINCLAS software (Verma et al., 2002, 2003).

$\mathrm{Sr}$ and $\mathrm{Nd}$ isotope analysis (Table 10 in Appendix A Supplementary Material) for eleven SC rocks were performed at Pacific Centre for Isotopic and Geochemical Research, University of British Columbia (Vancouver, Canada). Analyses were carried out on a Thermo Finnigan Triton thermal ionization mass spectrometer. De- 
tailed analytical procedures were reported by Weiss et al. (2006). Repeated analysis of SRM987 Sr standard ( $\mathrm{n}=$ $5)$ and La Jolla standard $(n=7)$ gave average values of $0.710248 \pm 15$ and $0.511854 \pm 17$. The analytical errors for ${ }^{87} \mathrm{Sr} /{ }^{86} \mathrm{Sr}$ and ${ }^{143} \mathrm{Nd} /{ }^{144} \mathrm{Nd}$ measured ratios are directly quoted for each sample.

\section{Petrography and mineral chemistry}

Petrographic and electron microprobe analysis reveal the existence of three mineralogical groups: (a) felsic rocks of dacitic composition $(\mathrm{F})$; (b) intermediate and felsic rocks (andesite to dacite) with disequilibrium evidence (FDE); and (c) chilled magmatic enclaves with an andesitic composition (ME) hosted in some lavas with disequilibrium evidence, whose distinctive features are reported in the next paragraphs.

\subsection{Felsic rocks $(F)$}

This group (Table 1 in in Appendix A) includes samples showing porphyritic or vesicular-porphyritic textures. Four different phenocryst assemblages are observed: (a) $\mathrm{Pl}+\mathrm{Qz}+\mathrm{Amp}$, (b) $\mathrm{Pl}+\mathrm{Amp}$, (c) Opx $+\mathrm{Pl}+\mathrm{Amp}$, and (d) Opx $+\mathrm{Cpx}+\mathrm{Pl}$. Euhedral to subhedral phenocrysts are embedded in an essentially vitreous groundmass with plagioclase and pyroxene microlites. Plagioclase (0.8-4.0 $\mathrm{mm})$, displaying andesine core compositions $\left(\mathrm{An}_{31-40}\right.$; Table 2 in Appendix A, and Fig. 3A), is the most abundant phenocryst type (60-75 modal \%). It generally shows normal zoning and polysynthetic and Carlsbad twins, and contains apatite and Fe-Ti oxides inclusions. Amphibole occurs as strongly pleochroic, yellow to brown, euhedral or subhedral crystals $(0.7-2.0 \mathrm{~mm}$ in length), occasionally forming clots. It has been classified as calcic amphibole (ferri-magnesiohastingsite; Table 4 in Appendix A, and Fig. 4A,B) using the NEWAMPHCAL software (Yavuz, 1999), based on the Leake et al. (1997) scheme, with a relatively high concentration of Si (6.7-6.9, apfu) and low Al content (1.2-1.4, apfu). Prismatic orthopyroxene $(0.5-1.0 \mathrm{~mm})$ display hypersthene core composition $\left(\mathrm{En}_{62-68} \mathrm{Fs}_{28-37} ;\right.$ Table 5 in Appendix A, and Fig. 5A). SC10 and SC20 rocks, from SCS sector, also include euhedral to subhedral clinopyroxene $(0.5-0.8 \mathrm{~mm})$ and a few hypersthene phenocrysts showing a narrow continuously zoned clinopyroxene rim.

\subsection{Felsic rocks with disequilibrium evidence (FDE)}

Most of the collected SC rocks ( $\sim 70 \%$ distributed along all sectors; Table 1 in Appendix A) have been integrated in this group. FDE lavas are generally porphyritic, showing flow texture and sometimes vesicles. Phenocrysts are
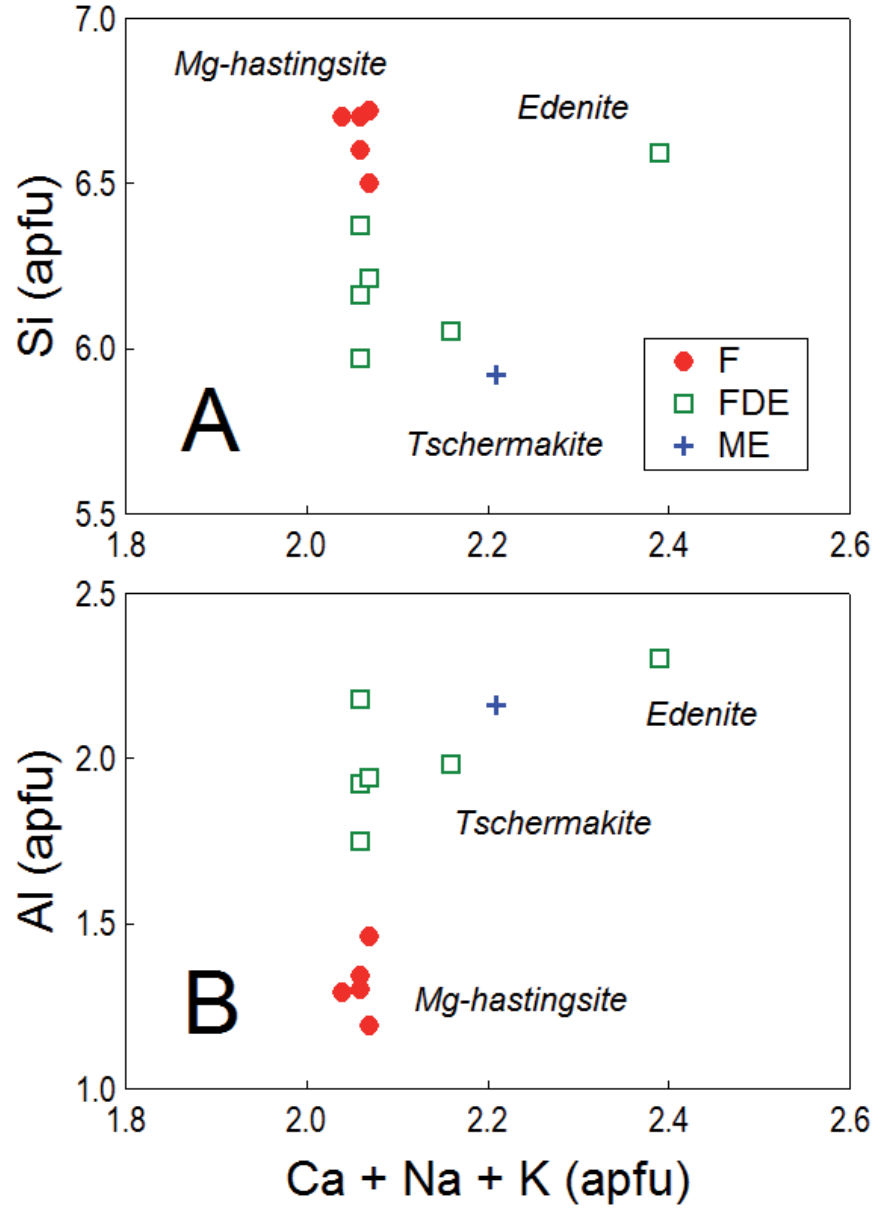

Fig. 4.- Amphibole compositions for SC magmas in terms of cations per structural formula unit (23 oxygens): (A) $\mathrm{Si}-\mathrm{Ca}+\mathrm{Na}+\mathrm{K}$ diagram, and (B) $\mathrm{Al}-\mathrm{Ca}+\mathrm{Na}+\mathrm{K}$ diagram.

Fig. 4.- Composición de anfíbol para magmas de la SC en términos de cationes por unidad de fórmula estructural (23 oxígenos): (A) diagra$\mathrm{ma} \mathrm{Si}-\mathrm{Ca}+\mathrm{Na}+\mathrm{K}$ y (B) diagrama $\mathrm{Al}-\mathrm{Ca}+\mathrm{Na}+\mathrm{K}$.

embedded in a microlitic groundmass, mainly constituted by plagioclase and amphibole. However, some rocks display either vitreous or trachytic matrix. Considering phenocryst assemblages, these rocks can be divided into five major groups: (a) $\mathrm{Ol}+\mathrm{Pl} \pm \mathrm{Amp} \pm \mathrm{Opx} \pm \mathrm{Qz}$; (b) $\mathrm{Pl}+$ $\mathrm{Opx} \pm \mathrm{Cpx} \pm \mathrm{Qz}$; (c) $\mathrm{Pl}+\mathrm{Amp}+\mathrm{Qz}$; (d) $\mathrm{Pl}+\mathrm{Amp}+\mathrm{Qz}$ $\pm \mathrm{Opx} \pm \mathrm{Cpx}$; (e) $\mathrm{Pl}+\mathrm{Amp}+\mathrm{Opx} \pm \mathrm{Cpx}$.

Additionally, FDE rocks exhibit the following distinctive characteristics: (a) diverse disequilibrium textures including sieved plagioclase, normal and sieved plagioclases in the same sample, rounded and embayed crystals, and reaction rims (Fig. 6A-D); (b) occurrence of vesicular, rounded or ellipsoidal andesitic magmatic enclaves (Fig. 6E-F); and (c) unusual mineral compositions, such as heterogeneous plagioclase core and rim compositions, and complex mineral zoning (reverse and oscillatory zoning in crystals or normally and reversely zoned crystals in the same sample). 


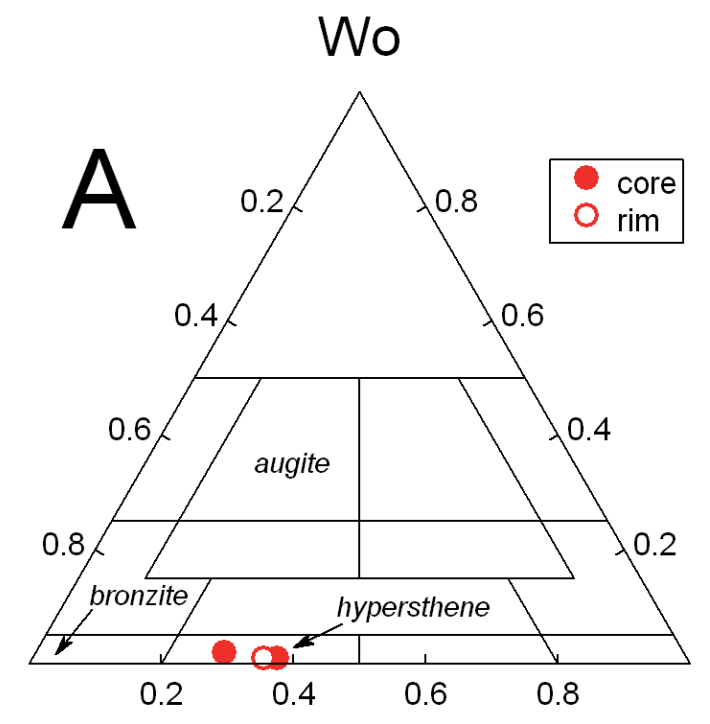

En

Fs

Fig. 5.- Compositional variations of pyroxene in SC magmas: (A) F group: felsic magmas, (B) FDE group: felsic magmas with disequilibrium evidence, and (C) ME group: chilled magmatic enclaves. Location and texture of the pyroxene analysis are indicated by symbol shape. Abbreviations: En = enstatite, Fs = ferrosilite, $\mathrm{Wo}_{\mathrm{o}}=$ wollastonite.

Fig. 5.- Variación composicional de piroxeno en magmas de la SC: (A) Grupo F: magmas félsicos, (B) Grupo FDE: magmas félsicos con evidencia de desequilibrio y (C) Grupo ME: enclaves magmáticos. La ubicación y textura de los análisis de feldespato se indican por la forma del símbolo. Abreviaturas: $\mathrm{En}=$ enstatita, $\mathrm{Fs}=$ ferrosilita, $\mathrm{Wo}_{\mathrm{N}}=$ wollastonita.

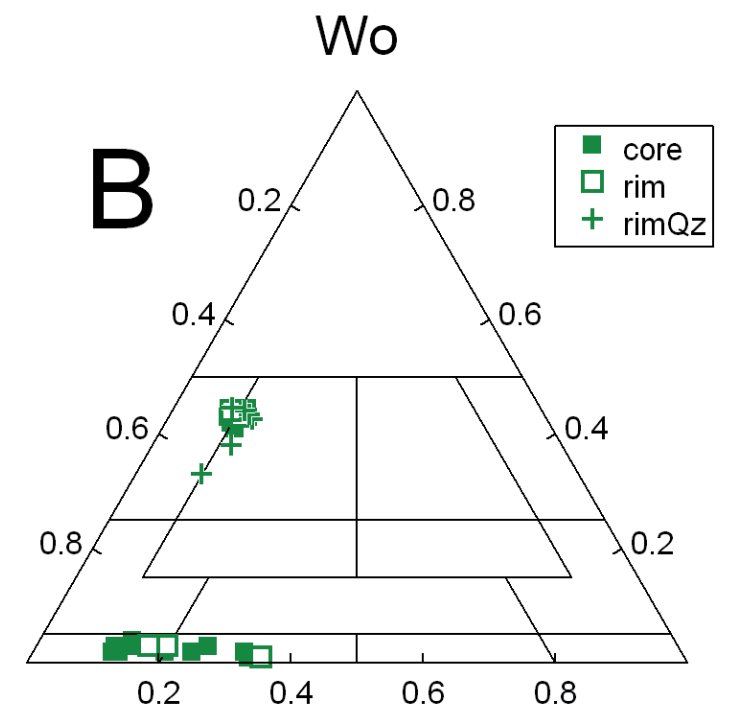

En

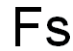

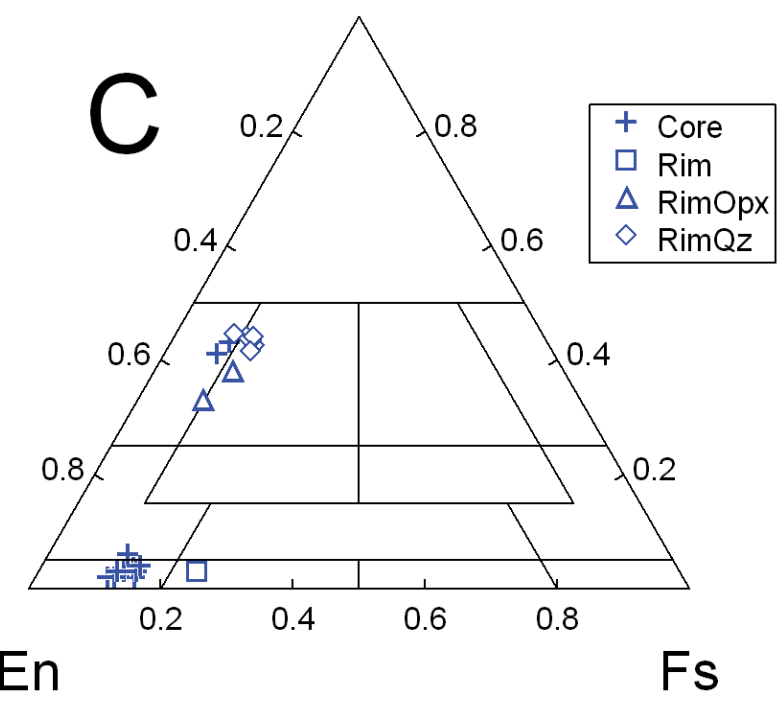

Plagioclase occurs as euhedral or subhedral phenocrysts $(0.5-8 \mathrm{~mm})$, showing Carlsbad or polysynthetic twinning. Crystals with clear and sieved texture can be observed in the same lava (Fig 6C,D). Core compositions in clear texture plagioclase vary from $\mathrm{An}_{30}$ to $\mathrm{An}_{51}$ (Table 2 in Appendix A, and Fig. 3B). They show normal zoning with rims of $\mathrm{An}_{32-43}$. Sieved plagioclase shows disequilibrium or resorption rims, although occasionally sieved-cored crystals are also observed. In comparison with clear texture crystals, sieved plagioclase exhibits a restricted range composition of labradorite $\left(\mathrm{An}_{51-61}\right.$; Table 2 in Appendix A). Additionally, an oscillatory zoning has been detected in several sieved plagioclase crystals (Table 3 in Appendix A), where the more calcic composition is observed in the dusty zones (Fig. 7). Some plagioclase phenocrysts show acicular apatite inclusions. On the other hand, FDE lavas include acicular Na-rich plagioclase microphenocrysts, one of them displaying an Or-rich

composition $\left(\mathrm{Ab}_{59-75} \mathrm{Or}_{3-19}\right.$; Table 2, Fig. 3B).

Amphibole phenocrysts $(0.8-4.0 \mathrm{~mm})$, with intense green to reddish brown pleochroism, cover a variety of compositions, probably as a product of a polybaric crystallization (Hammarstrom and Zen, 1986). In accordance with Leake et al. (1997) classification scheme, they are calcic, showing Fe-tschermakite, Fe-Mg-hastingsite or K-edenite compositions (Table 4 in Appendix A Supplementary Material, and Fig. 4A,B). Thin opaque rims, presumably formed by oxidation, are found on many crystals and locally Fe-Ti oxides appear to have replaced entire phenocrysts.

Euhedral or subhedral orthopyroxene $(0.5-2.0 \mathrm{~mm})$ occurred as isolated crystals or glomeroporphyritic aggregates, displaying bronzite $\left(\mathrm{En}_{82-86}\right)$ or hypersthene $\left(\mathrm{En}_{64-79}\right)$ core compositions (Table 5 in Appendix A Supplementary Material, and Fig. 5B). SC FDE lavas include both normally and reversely zoned orthopyroxene (rim: 

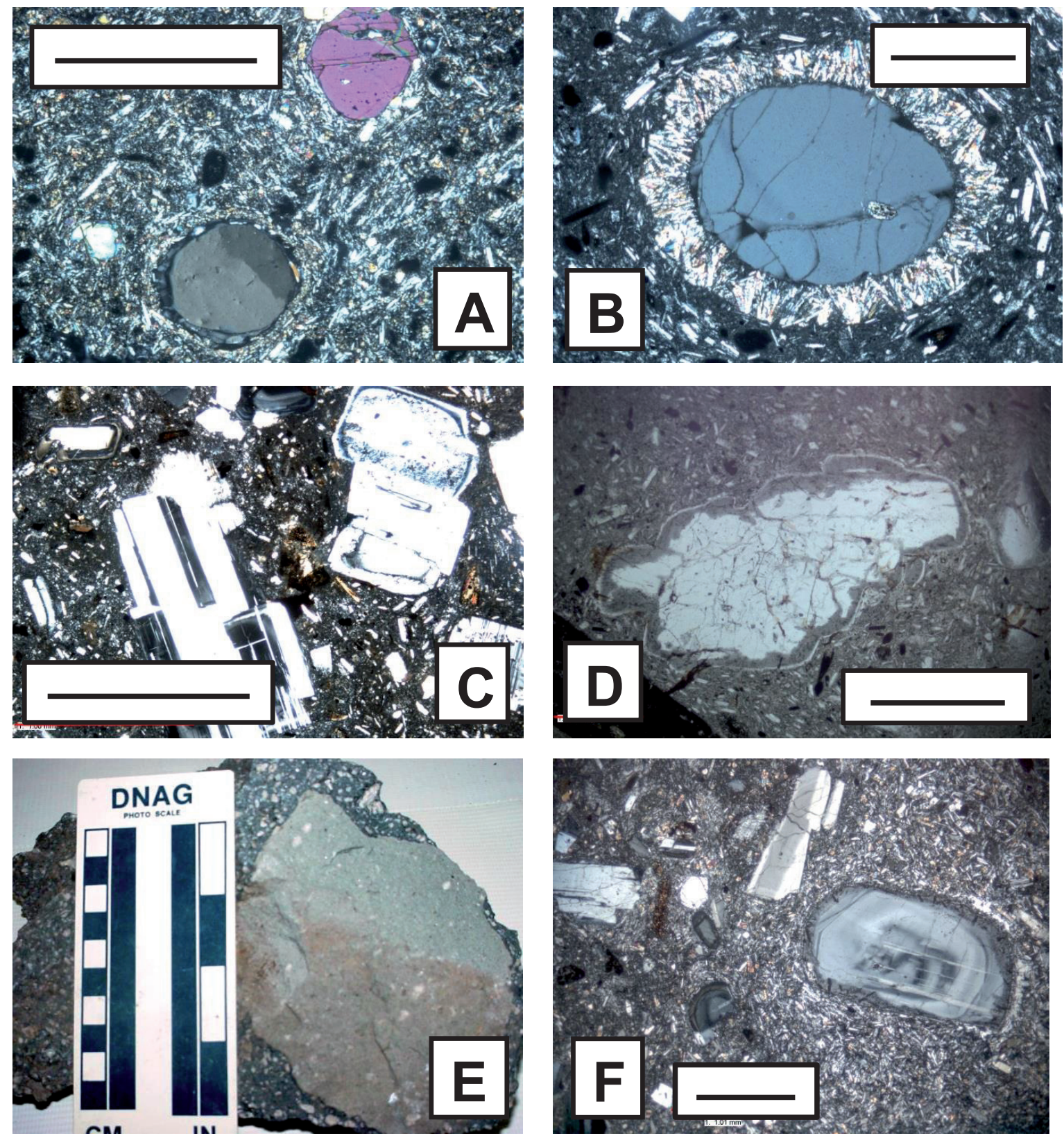

Fig. 6.- Photomicrographs of SC volcanic rocks (scale bar represents $1.0 \mathrm{~mm}$ ): (A) Occurrence of both olivine and quartz phenocrysts in andesite SC5, crossed polarized light; (B) Rounded quartz phenocryst with clinopyroxene reaction rim in dacite SC40, crossed polarized light; (C) Occurrence of both sieved-rimmed and normal zoned plagioclases in dacite SC32, crossed polarized light; (D) Sieved-rimmed plagioclase crystal in dacite SC43, plane polarized light; (E) Andesitic enclave (right; diameter $\sim 11 \mathrm{~cm}$ ) included in porphyritic dacite SC49; (F) Andesitic enclave (right) within porphyritic dacite SC29. A sieved-rimmed plagioclase phenocryst is surrounded by enclave, crossed polarized light.

Fig. 6.- Microfotografias de rocas volcánicas de la SC (escala representa $1.0 \mathrm{~mm}$ ): (A) Fenocristales de olivino y cuarzo presentes en la andesita SC5, nicoles cruzados; (B) fenocristal redondeado de cuarzo con borde de reacción de clinopiroxeno en la dacita SC40, nicoles cruzados; (C) Plagioclasas con borde en textura de red y con zonación normal en la dacita SC32, nicoles cruzados; (D) Cristal de plagioclasa con borde en textura de red en la dacita SC43, nicoles planos, (E) Enclave andesítico (derecha: diámetro $\sim 11 \mathrm{~cm}$ ) incluido en la dacita porfirítica SC49; (F) Enclave andesítico (derecha) dentro de la dacita porfirítica SC49. Un fenocristal de plagioclasa con borde en textura de red es rodeado por el enclave, nicoles cruzados.

$\left.\mathrm{En}_{64-80}\right)$. Some orthopyroxene crystals may also support narrow augitic rims $\left(\mathrm{En}_{50-57} \mathrm{Fs}_{10-12} \mathrm{Wo}_{50-57}\right.$; Table 6 in Appendix A Supplementary Material). Isolated calcic pyroxenes $(0.5-2.0 \mathrm{~mm})$ are included as euhedral phenocrysts with augitic composition $\left(\mathrm{En}_{45-48} \mathrm{Fs}_{9-12} \mathrm{Wo}_{42-44}\right.$; Table

\section{6, Fig. 5B).}

Anhedral quartz $(<2.0 \mathrm{~mm})$ occurs in some SC FDE lavas, showing an undulated extinction and sometimes reaction rims of acicular augite $\left(\mathrm{En}_{44-47} \mathrm{Fs}_{9-13} \mathrm{Wo}_{43-45} ;\right.$ Table 6, Fig. 5B). These coronae generally occur a short distance 


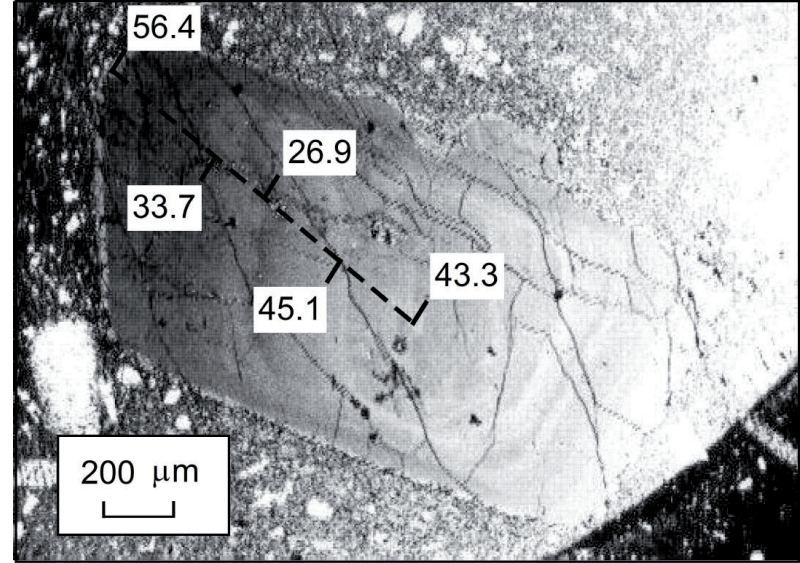

Fig. 7.- SEM image for sieved-rimmed plagioclase crystal, showing oscillatory zoning, in SC29 dacite. Numbers indicate \%An.

Fig. 7.- Imagen de microscopía de barrido electrónico de un cristal de plagioclasa con borde en textura de red, que muestra una zonación oscilatoria, en la dacita SC29. Los números indican \%An.

away from the edge of the quartz crystal suggesting nucleation within the boundary layer melt (Nixon, 1988a).

Mineralogical assemblage in this group is complemented with anhedral Fe-Ti oxides microphenocrysts $(<250$ $\mu \mathrm{m})$. According to the recalculation method suggested by Stormer (1983), titanomagnetite and ilmenite compositions have the range $\% \mathrm{~mol}_{\mathrm{Usp}}=13-19$ and $\% \mathrm{~mol}_{\mathrm{Ilm}}=67-89$, respectively (Table 7 in Appendix A Supplementary Material). They occur separately as well as in intimate contact. However, thermodynamic data have not been calculated as the $\mathrm{Mg} / \mathrm{Mn}$ partition test of Bacon and Hirschmann (1988) has not been validated by the oxide pairs.
SC FDE lavas collected in Cantimplora (SC4 and SC5) and Rancho Agustín localities (SC14 and SC15) from SCT sector have a high content $(70-80 \%$ in phenocryst mode) of euhedral to subhedral (skeletal) olivine phenocrysts $(0.7-2.0 \mathrm{~mm})$. Additionally, olivine $(<1.5 \mathrm{~mm})$ has also been observed in Peña de Lobos (SC49 from SCN sector) and Ajusco34 (SC1 from SC-SCh transition sector) outcrops, although its modal abundance is $\sim 5 \%$. Some SC olivine phenocrysts exhibit partial iddingsitization indicated by the development of red-clay and $\mathrm{Fe}$ oxyhydroxide. Olivine compositions extend from $\mathrm{Fo}_{87-90}$ (core) to $\mathrm{Fo}_{75-88}$ (rim), generally showing normal zoning (Table 7 in Appendix A).

\subsection{Chilled magmatic enclaves (ME)}

In the present study, seven ME (SCN sector: SC43a, SC49a, and SC49b; SCC sector: SC35a and SC37a; SCS sector: SC29a and SC57a; SC-SCh transition sector: $\mathrm{SC} 24 \mathrm{a}$; Table 1) were separated from their host dacites. They are darker than their host rock and display a porphyritic texture, with plagioclase, orthopyroxene, amphibole, and quartz phenocrysts in a microlitic groundmass mainly composed of acicular plagioclase and accessory opaque minerals. Some ME (SC49a,b) additionally contain scarce olivine phenocrysts $\left(\mathrm{Fo}_{88-90}\right.$; Table 7 in Appen$\operatorname{dix}$ A).

Euhedral plagioclase $(<3.0 \mathrm{~mm})$ displays core compositions ranging from andesine to labradorite $\left(\mathrm{An}_{33-48}\right.$; Table 2, Fig. 3C). Some plagioclase phenocrysts include acicular apatite inclusions. Some plagioclase phenoc-
Fig. 8.- Total alkali-silica (TAS; Le Bas et al., 1986) diagram for SC volcanic rocks. $\mathrm{BA}=$ basaltic andesite, $\mathrm{A}=$ andesite, $\mathrm{TA}$ $=$ trachyandesite, $\mathrm{D}=$ dacite.

Fig. 8.- Diagrama de álcalis totals - sílice (TAS; Le Bas et al., 1986) para las rocas volcánicas de la SC. BA= andesita basáltica, $\mathrm{TA}=$ traquiandesita, $\mathrm{D}=$ dacita.

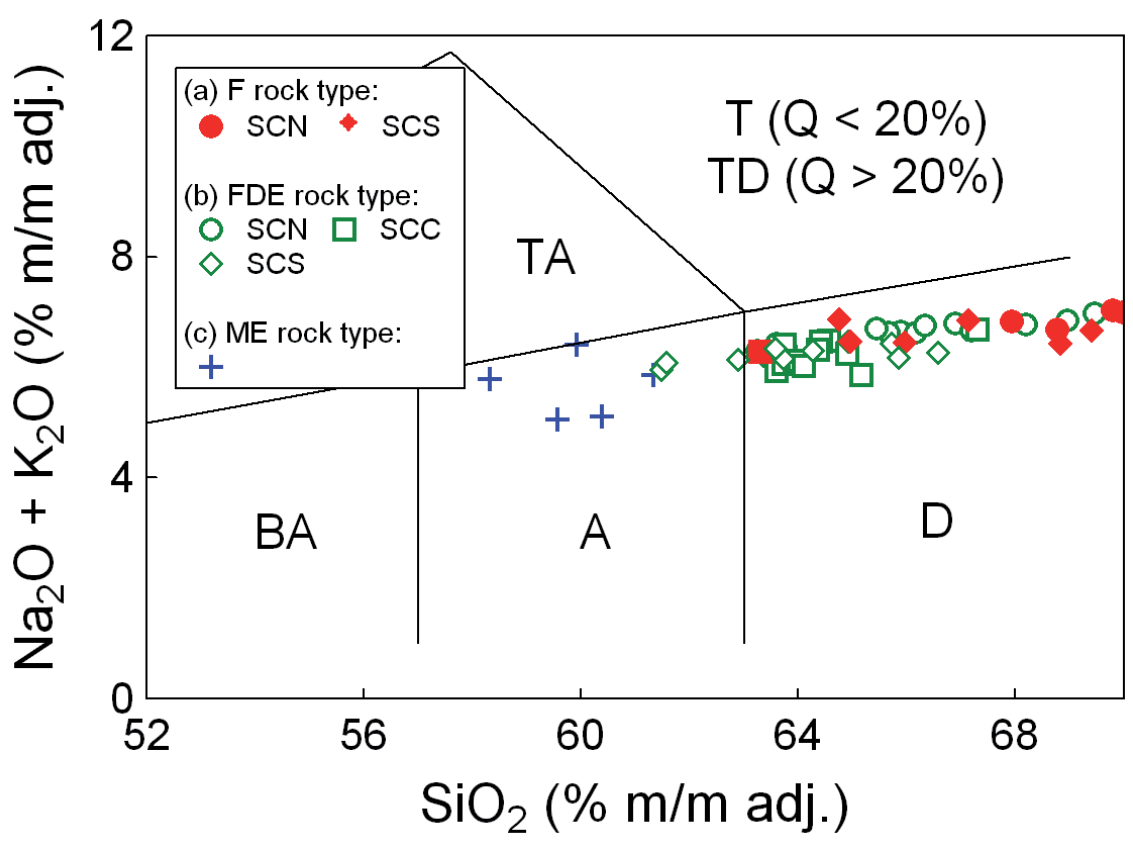


Fig. 9.- Harker variation diagrams for major elements. Symbols for volcanic rocks as in Figure 8.

Fig. 9.- Diagramas de variación Harker para elementos mayores. Los símbolos para rocas volcánicas como en la Figura 8.
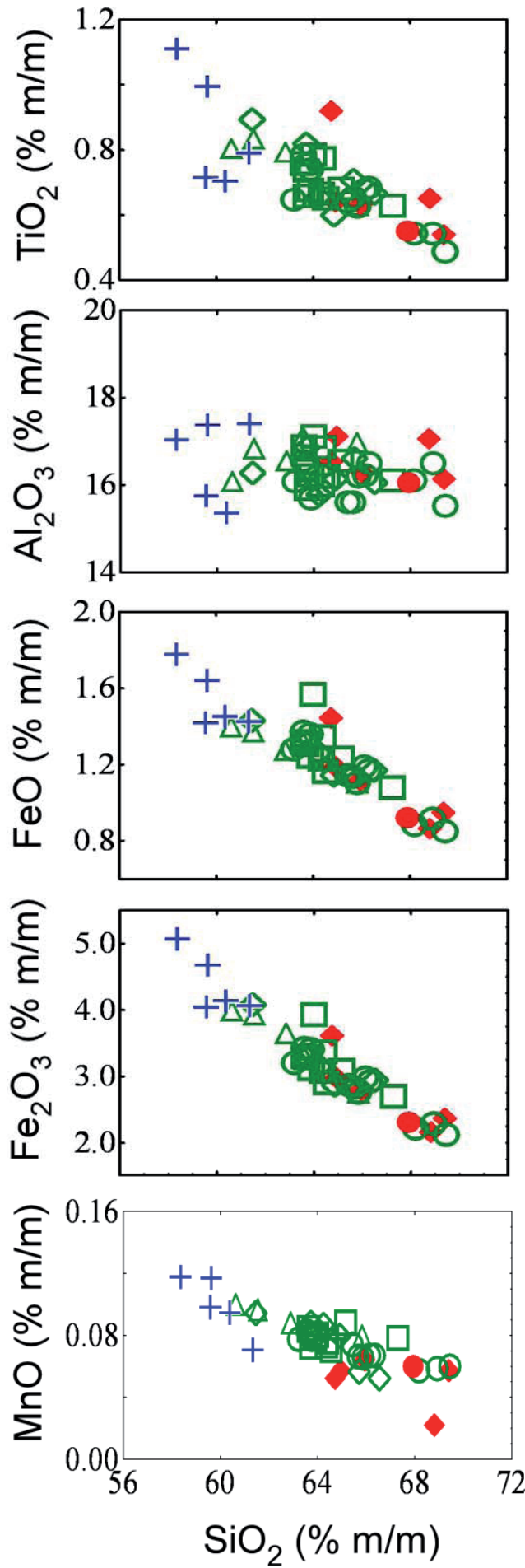
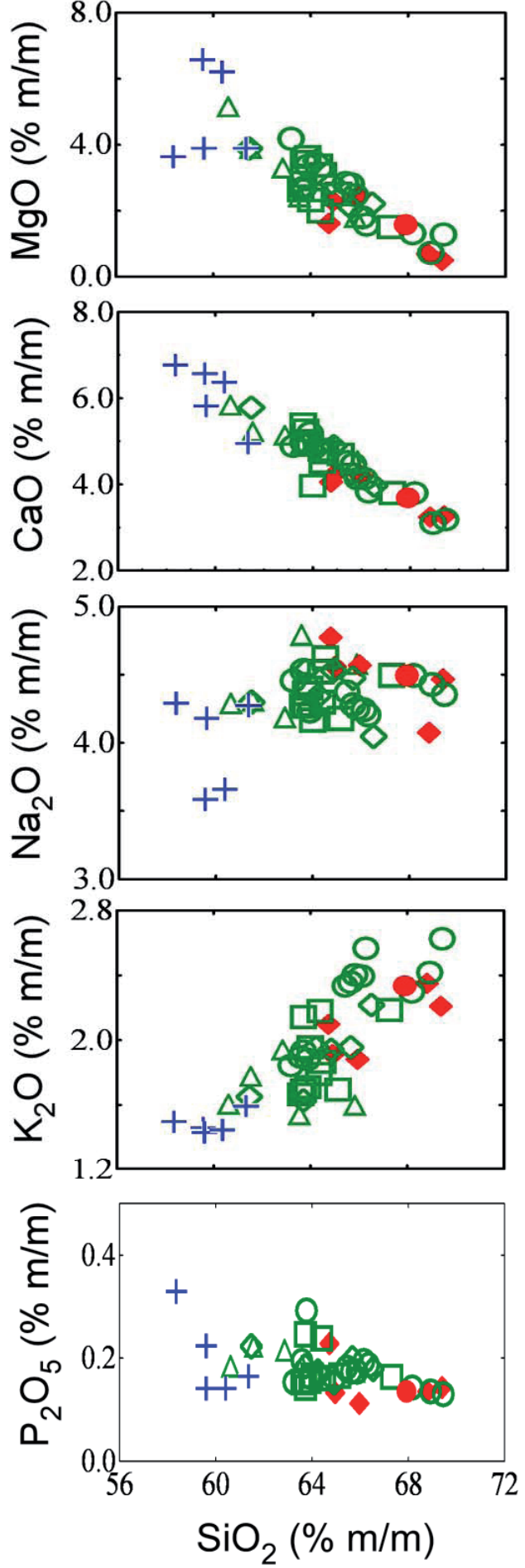

rysts show oscillatory zoning and are sieve-ringed, with a clear core mantled by a resorption zone $\left(\mathrm{An}_{40-59}\right)$. As observed in andesitic-dacitic lavas showing disequilibrium features, acicular K-rich plagioclase microphenocrysts $\left(\mathrm{Or}_{14}\right)$ occur in the enclaves.

Orthopyroxene $(>1.5 \mathrm{~mm})$ occurs as sparse phenocrysts, displaying a hypherstene and bronzite composition $\left(\mathrm{En}_{73-87} \mathrm{Fs}_{11-24} \mathrm{Wo}_{2-6}\right.$; Fig. 5C). An amphibole phenocryst $(1.1 \mathrm{~mm})$ is calcic, following the Leake et al. (1997) clas- sification scheme, with a tschermakite composition (Table 4 in Appendix A, Fig. 4A,B). This crystal display Si (5.9, apfu) and $\mathrm{Al}(2.2$, apfu) values similar to tschermakite from dacites without disequilibrium features. Subhedral to anhedral quartz xenocrysts $(<1.0 \mathrm{~mm})$ with irregular cracks and undulated extinction complete the enclave mineral assemblage. Some of them display augitic thin rims ( $\mathrm{En}_{44-46} \mathrm{Fs}_{12-13} \mathrm{Wo}_{42-44}$; Table 6 in Appendix A). 

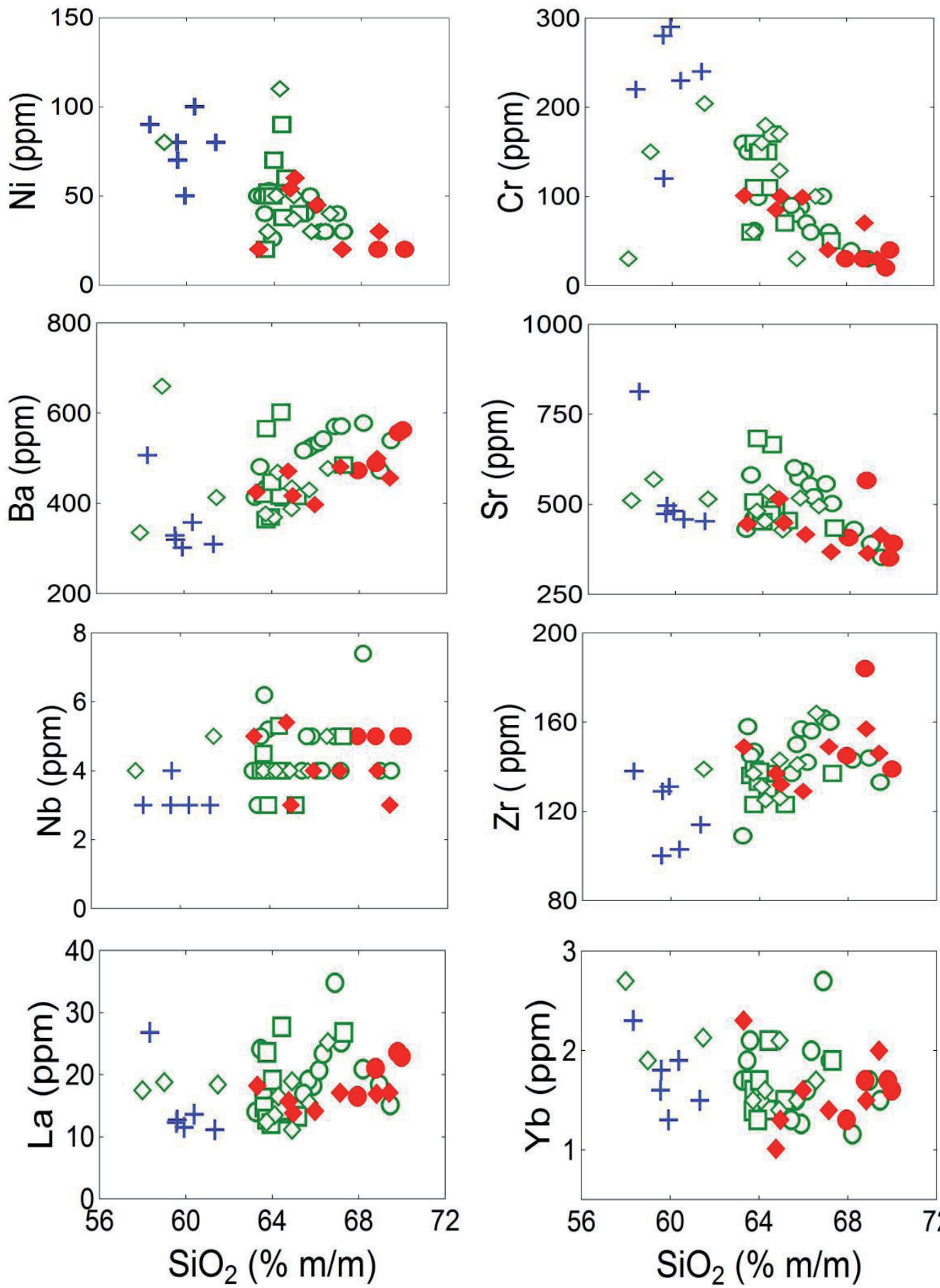

Fig. 10.- Harker variation diagrams for trace elements. Transition elements: $\mathrm{Ni}$ and $\mathrm{Cr}$, lithophile elements: $\mathrm{Ba}$ and $\mathrm{Sr}$, high-field strength elements: $\mathrm{Nb}$ and $\mathrm{Zr}$, rare earth elements: $\mathrm{La}$ and $\mathrm{Yb}$. Symbols for volcanic rocks as in figure 8 .

Fig. 10.- Diagramas de variación Harker para elementos traza. Elementos de transición: $\mathrm{Ni}$ y $\mathrm{Cr}$, elementos litófilos: $\mathrm{Ba}$ y $\mathrm{Sr}$, elementos de campo electrostático fuerte: $\mathrm{Nb}$ y $\mathrm{Zr}$, elementos de las tierras raras: La e Yb. Los símbolos para rocas volcánicas como en la figura 8 .

\section{Whole-rock geochemistry and isotopic ratios}

\subsection{Major elements}

The $\mathrm{F}$ lavas have a dacitic composition (Fig. 8), covering a range of $\mathrm{SiO}_{2}=63.7-69.4 \%$ and $\left(\mathrm{Na}_{2} \mathrm{O}+\mathrm{K}_{2} \mathrm{O}\right)$ $=6.4-6.9 \mathrm{wt} \%$, with $\mathrm{MgO}=0.5-2.4 \mathrm{wt} \%$. In contrast, the ME could be considered as andesites (Fig. 8) displaying, in comparison to $\mathrm{F}$ lavas, lower $\mathrm{SiO}_{2}(=58.3-61.3$ $\%)$ and $\left(\mathrm{Na}_{2} \mathrm{O}+\mathrm{K}_{2} \mathrm{O}\right)(=5.1-5.9 \%)$ values, as well as higher $\mathrm{MgO}$ contents $(=3.9-6.6 \%)$. FDE lavas display a range of major element compositions varying from andesite (restricted to SCC and SCS sectors) to dacite. These rocks have $\mathrm{SiO}_{2}(=60.6-68.2 \%), \mathrm{Na}_{2} \mathrm{O}+\mathrm{K}_{2} \mathrm{O}(=$ 5.9-6.8 \%), and $\mathrm{MgO}$ (=1.3-5.1\%) concentrations that are intermediate between the $\mathrm{F}$ lavas and $\mathrm{ME}$.

On Harker diagrams, all major elements contents decrease with increasing $\mathrm{SiO}_{2}$, except alkalis and $\mathrm{Al}_{2} \mathrm{O}_{3}$ (Fig. 9). $\mathrm{Na}_{2} \mathrm{O}$ and $\mathrm{Al}_{2} \mathrm{O}_{3}$ do not change whereas $\mathrm{K}_{2} \mathrm{O}$ increases with $\mathrm{SiO}_{2}$. It is important to note that the most silicic FDE lavas overlap the $\mathrm{F}$ dacites without disequilibrium texture. 
Fig. 11.- Chrondrite-normalized REE plots for representative SC volcanic rocks: (A) Felsic magmas (F): SC45 and SC21, (B) Felsic magmas with disequilibrium evidence (FDE): SC25, SC39, SC31, and SC23, (C) Chilled magmatic enclaves (ME): SC37a and SC49b. Average chondrite values ( $\mathrm{ppm}$ ) used for normalization are from Nakamura (1974) and Haskin et al. (1968): $\mathrm{La}=0.329, \mathrm{Ce}=0.865, \mathrm{Pr}=0.112, \mathrm{Nd}$ $=0.63, \mathrm{Sm}=0.203, \mathrm{Gd}=0.276, \mathrm{~Tb}=0.047, \mathrm{Dy}=$ $0.343, \mathrm{Ho}=0.07, \mathrm{Er}=0.225, \mathrm{Tm}=0.03, \mathrm{Yb}=0.22$, and $\mathrm{Lu}=0.0339$.

Fig. 11.- Diagramas de elementos de las tierras raras normalizados a condrita para rocas volcánicas representativas de la SC: (A) Magmas félsicos (F): SC45 y SC21, (B) Magmas félsicos con evidencia de desequilibrio (FDE): SC25, SC39, SC31 y SC23 y (C) Enclaves magmáticos (ME): SC37a y SC49b. Valores promedio de condrita (ppm) utilizados para normalización de Nakamura (1974) y Haskin et al. (1968): $\mathrm{La}=0.329, \mathrm{Ce}=0.865, \mathrm{Pr}=0.112, \mathrm{Nd}=0.63, \mathrm{Sm}$ $=0.203, \mathrm{Gd}=0.276, \mathrm{~Tb}=0.047, \mathrm{Dy}=0.343, \mathrm{Ho}=$ $0.07, \mathrm{Er}=0.225, \mathrm{Tm}=0.03, \mathrm{Yb}=0.22$, and $\mathrm{Lu}=$ 0.0339 .

\subsection{Trace elements}

F dacites exhibit higher abundances of trace elements compared to most ME, with the exception of compatible elements, Sr, and Y. However, SC37a enclave (SCC sector) represents a special case, due to a marked enrichment in REE, $\mathrm{Ba}, \mathrm{Sr}, \mathrm{Zr}$ and $\mathrm{Y}$ compared to the other enclaves. Compatible and LILE variation diagrams versus $\mathrm{SiO}_{2}$ show that the $\mathrm{SC}$ rocks plot along a mixing line, although a considerable scatter exists (Fig. 10). REE (e.g., La, Yb) and HFSE (e.g., $\mathrm{Nb}, \mathrm{Zr}$ ) variation diagrams versus $\mathrm{SiO}_{2}$ display relatively flat trends showing a significant data dispersion.

Chondrite-normalized REE diagrams of all SC rocks (Fig. 11) are characterized by enrichment in light REE and a flat pattern for heavy REE. F dacites display significantly higher $(\mathrm{La} / \mathrm{Yb})_{\mathrm{N}}$ ratios $(=5.7-10.3)$ than the $\mathrm{ME}(=4.7-7.8)$, whereas FD-E lavas have ratios $(=4.7-$ 12.0) that overlap or exceed those of the other groups. All rocks lack a significant negative Eu anomaly, as would be expected by a prolonged fractionation of plagioclase, the most abundant phenocryst of the SC rocks. However, a slightly negative $\mathrm{Ce}$ anomaly is observed in some cases, which can be evaluated by the $\mathrm{Ce}_{\mathrm{N}} / \mathrm{Ce}^{*}{ }_{\mathrm{N}}$ parameter (= $\mathrm{Ce}_{\mathrm{N}} /\left[\mathrm{La}_{\mathrm{N}}{ }^{*} \operatorname{Pr}_{\mathrm{N}}\right]^{0.5}$; Seto and Akagi, 2008). Dacites lacking disequilibrium texture display a $\mathrm{Ce}_{\mathrm{N}} / \mathrm{Ce}^{*}{ }_{\mathrm{N}}=0.74-0.89$, a range comparable to the observed in $\operatorname{FDE}(=0.60-0.93)$ and $\mathrm{ME}(=0.81-0.93)$ rock types.

Primitive mantle-normalized multi-element diagrams for SC groups (Fig. 12) are characterized by a zig-zag pattern, with negative anomalies in HFSE (Th, Nb, Ta, and $\mathrm{Ti}$ ) and $\mathrm{P}$, and a general trend where the abundance diminishes as compatibility increases.

\subsection{Nd and Sr isotopic ratios}

Available $\mathrm{Sr}$ and $\mathrm{Nd}$ isotopic information for SC rock types are summarized in Table 10 (in Appendix A Supplementary Material). ${ }^{87} \mathrm{Sr} /{ }^{86} \mathrm{Sr}$ values of these rocks range from 0.703917 to 0.704268 , whereas ${ }^{143} \mathrm{Nd} /{ }^{144} \mathrm{Nd}$ ratios cover the narrow interval from 0.512812 to 0.512903 . All samples fall within the "mantle array", shown schematically by small dashed lines in the ${ }^{87} \mathrm{Sr} /{ }^{86} \mathrm{Sr}-{ }^{143} \mathrm{Nd} /{ }^{144} \mathrm{Nd}$ diagram (Fig. 13), overlapping with the Mexican lower crust (Patchett and Ruiz, 1987; Ruiz et al., 1988a,b; Roberts and Ruiz, 1989; Schaaf et al. 1994) and crustal xenoliths of Popocatépetl stratovolcano (Schaaf et al., 2005).

\section{Discussion}

Several mineralogical and geochemical features observed in SC rocks strongly indicate the involvement of magma mingling processes during the 3.6 to 0.4 Ma period of development of the SC stratovolcanoes.

\subsection{Magma mingling mineralogical evidence}

Sieve texture, as observed in FDE (for example, Fig. 6D) and ME (for example, Fig. 6F), has been described (Tsuchiyama, 1985; Shelley, 1993) as the small, interconnected inclusions of glass or other matrix material giving the crystal a porous appearance. Heating above the plagioclase liquidus temperature causes fusion of the phenocryst and a rounding off (resorption) of the crystal shape.

Normal and oscillatory zoning in plagioclase crystals in the same sample (for example, dacite SC29; Tables 2-3; 


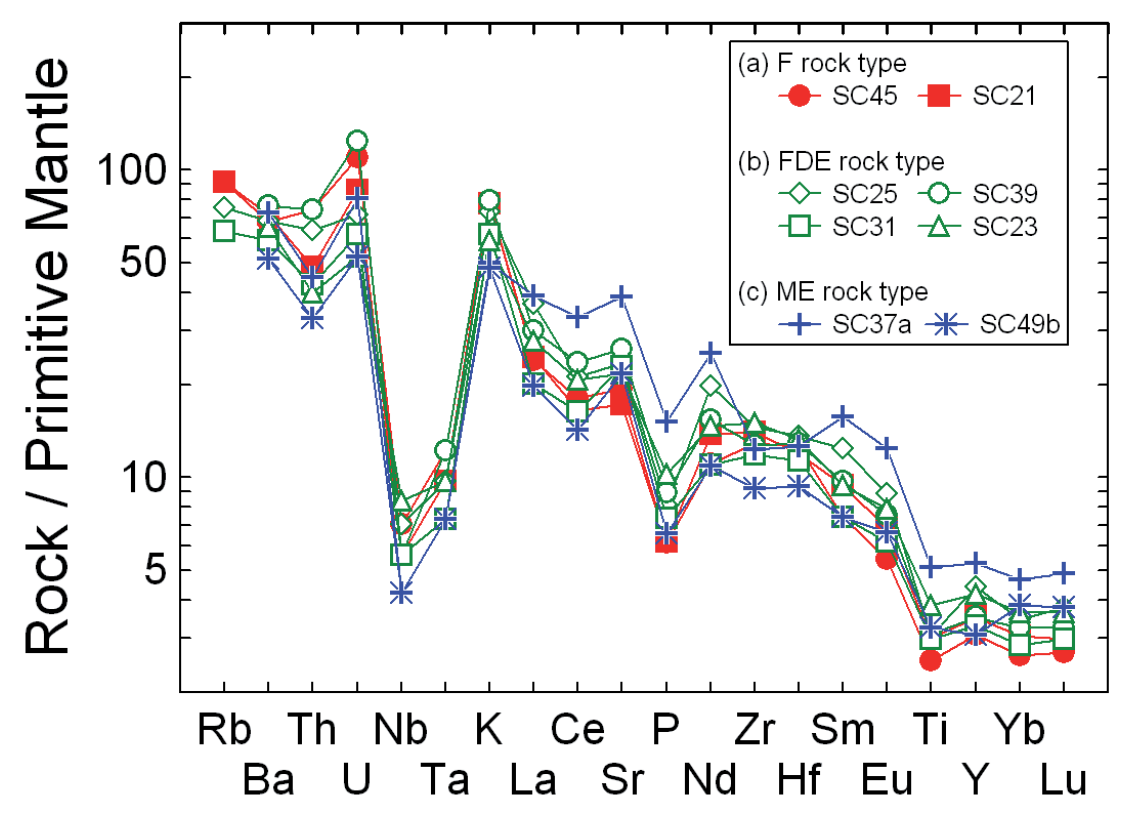

Fig. 12.- Primitive mantle-normalized multi-element diagrams for representative SC volcanic rocks: (a) Felsic magmas (F): SC45 and SC21, (b) Felsic magmas with disequilibrium evidence (FDE): SC25, SC39, SC31, and SC23, (c) Chilled magmatic enclaves (ME): SC37a and $\mathrm{SC} 49 \mathrm{~b}$. The primitive mantle values ( $\mathrm{ppm}$ ) for normalization are from Sun and McDonough (1989): $\mathrm{Rb}=$ $0.635, \mathrm{Ba}=6.989, \mathrm{Th}=0.085, \mathrm{U}=0.021, \mathrm{Nb}=0.713$, $\mathrm{Ta}=0.041, \mathrm{~K}=250, \mathrm{La}=0.687, \mathrm{Ce}=1.775, \mathrm{Sr}=21.1$, $\mathrm{P}=95, \mathrm{Nd}=1.354, \mathrm{Zr}=11.2, \mathrm{Hf}=0.309, \mathrm{Sm}=0.444$, $\mathrm{Eu}=0.168, \mathrm{Ti}=1300, \mathrm{Y}=4.55, \mathrm{Yb}=0.493$, and $\mathrm{Lu}$ $=0.074$.

Fig. 12.- Diagramas multi-elementos normalizados a manto primitivo para rocas volcánicas representativas de la SC: (A) Magmas félsicos (F): SC45 y SC21, (B) Magmas félsicos con evidencia de desequilibrio (FDE): SC25, SC39, SC31 y SC23 y (C) Enclaves magmáticos (ME): SC37a y SC49b. Valores promedio de manto primordial (ppm) utilizados para normalización de Sun y McDonough (1989): $\mathrm{Rb}=0.635, \mathrm{Ba}=6.989$, $\mathrm{Th}=$ $0.085, \mathrm{U}=0.021, \mathrm{Nb}=0.713, \mathrm{Ta}=0.041, \mathrm{~K}=250, \mathrm{La}$ $=0.687, \mathrm{Ce}=1.775, \mathrm{Sr}=21.1, \mathrm{P}=95, \mathrm{Nd}=1.354, \mathrm{Zr}$ $=11.2, \mathrm{Hf}=0.309, \mathrm{Sm}=0.444, \mathrm{Eu}=0.168, \mathrm{Ti}=1300$, $\mathrm{Y}=4.55, \mathrm{Yb}=0.493$, and $\mathrm{Lu}=0.074$.
Fig. 7) has been interpreted as consequence of a magma mingling process (Nakada, 1991). Nixon and Pearce (1987) reported repeated major sharp reversals in plagioclase crystals from Iztaccíhuatl dacites due to magma mixing caused by injection of fresh basic magma. This phenomenon has also been documented in other MVB localities (for example, Luhr and Carmichael, 1980; Wallace and Carmichael, 1994). Additionally, inverse zoning of orthopyroxene (for example, core/rim analysis for dacites SC31 and SC40; Table 5 in Appendix A) has been especially quoted as evidence of magma mingling behavior (Sakuyama, 1981; Bloomfield and Arculus, 1989).
Acicular plagioclase microphenocrysts displaying a K-rich composition (Fig. 3C) could be interpreted as micro-crystals produced by quenching, where $\mathrm{Na}$ atoms have been partially substituted by ion exchange $\mathrm{K}$ atoms at high temperature (e.g., Viswanathan, 1971; Kroll and Bambauer, 1981). K migration (diffusion coefficient $2.10^{-7} \mathrm{~cm}^{2} / \mathrm{sec}$ ) from felsic to mafic magmas during mingling, before the ME undercooling, has been reported by Kumar and Pieru (2010).

An effective blending is inhibited when temperature and viscosity contrasts between two magmas are large and when the proportion of the mafic/intermediate endmember magma is small (typically $<50 \%$ ), because the
Fig. 13.- ${ }^{87} \mathrm{Sr} /{ }^{86} \mathrm{Sr}-{ }^{143} \mathrm{Nd} /{ }^{144} \mathrm{Nd}$ plot for the SC rocks and their comparison with Mexican lower crust (Patchett and Ruiz, 1987; Ruiz et al. 1988a,b; Roberts and Ruiz 1989; Schaaf et al., 1994) and crustal xenoliths from Popocatépetl (Schaaf et al. 2005). The "Mantle-array" (dashed lines) is included for reference (Faure, 1986). All mantle components named after Zindler and Hart (1986) are: BSE- bulk silicate earth or PUM- primitive uniform mantle reservoir; PREMA- prevalent mantle composition; HIMU- high U/ $\mathrm{Pb}$ mantle component.

Fig. 13.- Diagrama ${ }^{87} \mathrm{Sr} /{ }^{86} \mathrm{Sr}^{-143} \mathrm{Nd} /{ }^{144} \mathrm{Nd}$ par alas rocas volcánicas de la SC y su comparación con la corteza inferior mexicana (Patchett and Ruiz, 1987; Ruiz et al. 1988a,b; Roberts and Ruiz 1989; Schaaf et al., 1994) y xenolitos corticales del Popocatépetl (Schaaf et al. 2005). El "arreglo del manto" (líneas discontinuas) se incluye como referencia (Faure, 1986). Los componentes del manto denominados por Zindler y Hart (1986) son: BSE - Tierra silicatada global o PUM - manto uniforme primitivo; PREMA composición de manto prevalente; HIMU- componente de manto con alta relación $\mathrm{U} / \mathrm{Pb}$.

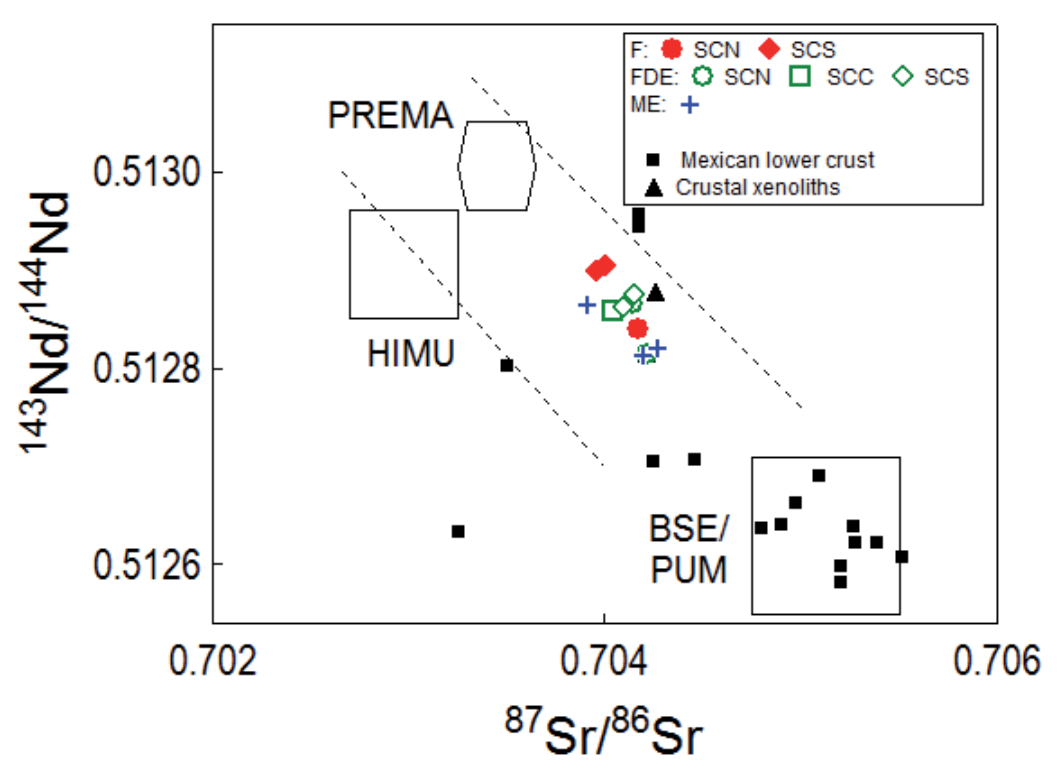



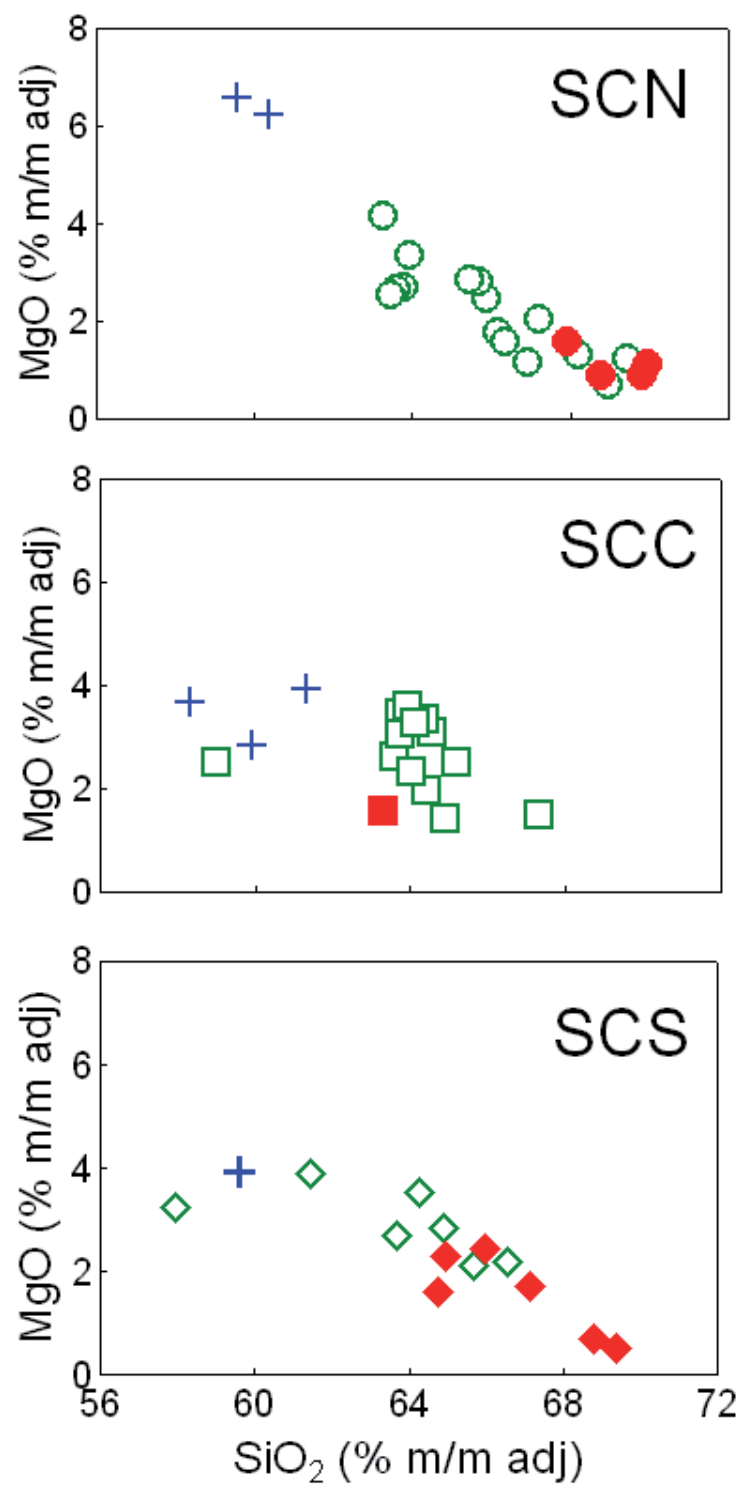

Fig. 14.- Harker diagram for $\mathrm{MgO}(\% \mathrm{~m} / \mathrm{m}$ adj. $)$ taking into account the sample distribution in the SC morphostructural sectors: (A) SCN, (B) SCC, and (C) SCS.

Fig. 14.- Diagrama de Harker para $\mathrm{MgO}(\% \mathrm{~m} / \mathrm{m}$ aj.) considerando la distribución de muestras en los sectores morfoestructurales de la SC: (A) SCN, (B) SCC y (C) SCS.

mafic/intermediate magma is undercooled to form isolated magmatic inclusions or enclaves in the felsic magma (Eichelberger, 1980; Bacon, 1986; Sparks and Marshall, 1986; Vernon et al., 1988; Stimac et al., 1990; Clyne, 1999; Gençalioğlu Kuşcu and Floyd, 2001; Coombs et al., 2002; Alpaslan et al., 2005). Some of the FDE rocks (see Table 1 and Fig. 6E,F) include rounded to ellipsoidal magmatic enclaves, which generally maintain coherent and sharp contacts with their host lavas. ME can be interpreted as quenched blobs of an andesitic magma that was injected into relatively cooler dacitic magma, displaying a non-Newtonian behavior within their host magma. A disparity in physical properties between andesitic enclaves and their host dacitic magmas probably leads to fast crys- tallization of the former magmatic enclaves, as indicated by the acicular character of some crystals (Sparks and Marshall, 1986; Blake and Fink, 2000).

\subsection{Magma mingling geochemical evidence}

Eichelberger et al. (2006) suggested that, rather than a liquid line of descent, the linear trends as those observed in the Harker major-element diagrams for SC lavas (Fig. 9) reflect a spectrum of discrete magma batches product of complex mingling processes between intermediate and silicic end-members. The lack of coherent trends on Harker trace-element diagrams (Fig. 10) also supports the argument that analyzed compositions did not follow simple liquid lines of descent, but rather reflect complex opensystem processes including partial mixing or mingling.

Trace element (including rare earths) Harker patterns, however, show partial to complete equilibration, most likely governed by different degrees of elemental dif-

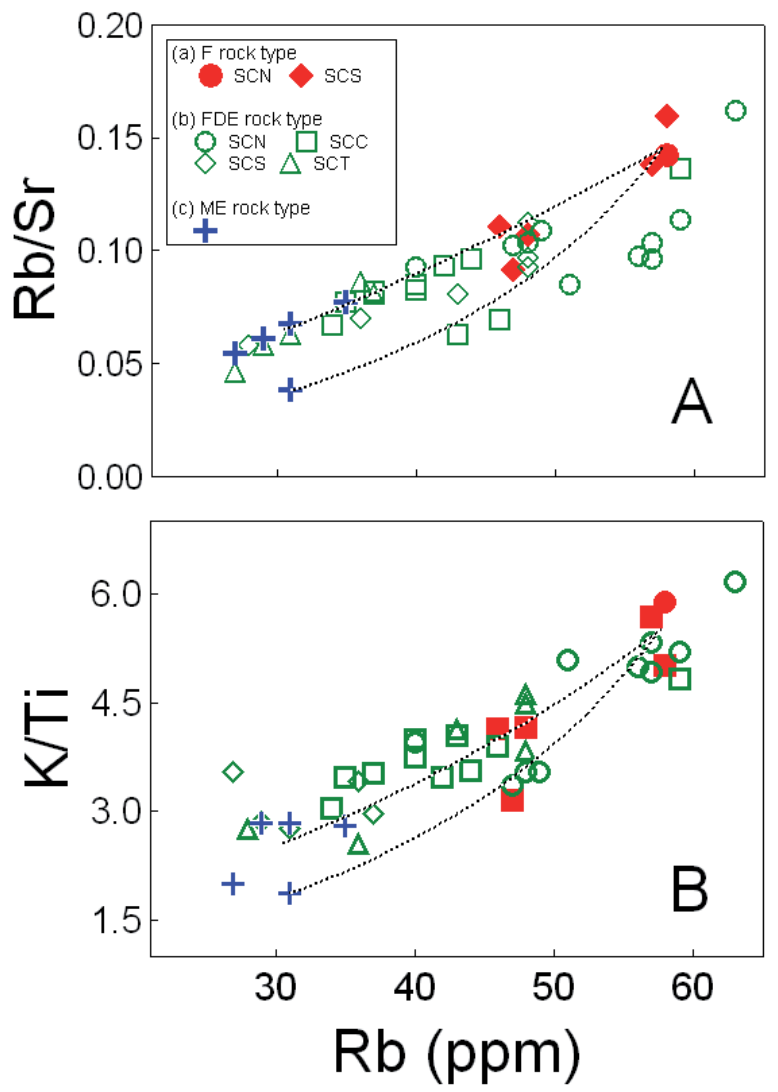

Fig. 15.- Trace element variation diagrams for SC volcanic rocks: (A) $\mathrm{Rb} / \mathrm{Sr}-\mathrm{Rb}$ and $(\mathrm{B}) \mathrm{K} / \mathrm{Ti}-\mathrm{Rb}$. The diagrams also show binary mixing models considering a dacitic and two andesitic end-members (SC37a and the average of rest of enclaves).Symbols for volcanic rocks as in figure 8 .

Fig. 15.- Diagramas de variación de elementos traza para las rocas volcánicas de la $\mathrm{SC}$ : (A) $\mathrm{Rb} / \mathrm{Sr}-\mathrm{Rb}$ y (B) $\mathrm{K} / \mathrm{Ti}-\mathrm{Rb}$. Los diagramas también incluyen modelos de mezcla binaria considerando un miembro final dacítico y dos andesíticos (SC37a y el promedio del resto de los enclaves). Símbolos para las rocas volcánicas como en la figura 8 . 
fusion. Additionally, at least one end-member must be compositionally heterogeneous, as reflected by the differences in trace element geochemistry of SC37a and the rest of andesitic enclaves.

It is important to note that, the Harker diagram linear arrays are product of several magma mingling events that occurred during the $\mathrm{SC}$ geological history, (e.g., $\mathrm{SiO}_{2}$ vs. $\mathrm{MgO}$ Harker plots, (Fig. 14). Taking into account the morphostructural SC sectors, the best defined linear arrangement is observed in the SCN sector, where: (a) the compositional contrast between the magmatic end-members is more pronounced, and (b) the magmatic enclave density per area is maximum, and its size reaching 20 $\mathrm{cm}$. Harker diagrams of SCC and SCS sectors are characterized by a greater dispersion, as: (a) the difference in composition of ME in relation to $\mathrm{F}$ rocks is lower, and (b) the number and size of enclaves decreases southward.

Low HFSE concentrations showed by SC rocks could be related to amphibole and ilmenite fractional crystallization, whereas $\mathrm{P}$ negative anomaly could be related to apatite fractionation (Rollinson, 1993). On the other hand, $\mathrm{Th} / \mathrm{Cs}(=2.5-3.5)$ and $\mathrm{Rb} / \mathrm{Cs}(=23-45)$ ratios in $\mathrm{ME}$ are similar to those of the continental crust $(\mathrm{Th} / \mathrm{Cs}$ $=2.1-4.0, \mathrm{Rb} / \mathrm{Cs}=17.1-36.7$; Rudnick and Gao, 2003). Crustal ratios are also observed in $\mathrm{F}$ lavas $(\mathrm{Th} / \mathrm{Cs}=1.5$ $2.8 ; \mathrm{Rb} / \mathrm{Cs}=15-40)$. This similarity in incompatible trace element ratios strongly suggests the crust as the potential source region for both rock types, although magma generation probably occurred at different depths. Nevertheless, crystal fractionation processes are not sufficient in order to explain the correlation between $\mathrm{Th} / \mathrm{Cs}$ and $\mathrm{Rb} /$ Cs ratios. Therefore, it is suggested that a partial mixing relationship superimposed on fractional crystallization is required to explain the $\mathrm{SC}$ volcanic rocks geochemistry.

Negative Ce anomalies, observed in chondrite-normalized REE diagrams, could result from incipient weathering (e.g., Patino et al., 2003), although no petrographic evidence has been detected in the $\mathrm{SC}$ volcanic rocks. Borg and Clyne (1998) suggested that upper-crustal assimilation might explain the negative $\mathrm{Ce}$ anomalies observed in felsic calc-alkaline magmas from the southernmost Cascades. However, REE patterns of crustal xenoliths from central MVB (Urrutia-Fucugauchi and Uribe-Cifuentes, 1999; Aguirre-Díaz et al., 2002) do not display negative Ce anomalies. Gómez-Tuena et al. (2006) have reported intermediate to felsic lavas from the Nevado de Toluca volcano characterized by negative $\mathrm{Ce}$ anomalies, being interpreted as evidence for slab-derived sedimentary contributions in the petrogenesis of the central MVB. However, REE normalized patterns for pelagic sediments from Site 487 located in the Cocos plate also show a significant negative Eu anomaly (Verma, 2000), which is not observed in the SC rock types. In such a way, negative Ce anomaly remains unexplained, as additional $\mathrm{Pb}$ isotopic information for SC lavas is necessary to understand this phenomenon.

Unfortunately, approximations of physical properties of magmas (e.g., pressure and temperature) cannot at present be evaluated because thermodynamic data are not still available for SC host dacitic and intruded andesitic magmas.

The formation of enclaves probably took place later in the mingling process, because the co-mingled lavas exhibit disequilibrium mineral textures and a geochemistry between the andesitic enclaves and the dacites. The partial mixing origin of FDE rocks can also be modeled based on the geochemical compositions of two end-members, particularly using trace elements (Rollinson, 1993). For example, in the $\mathrm{Rb} / \mathrm{Sr}$ and $\mathrm{K} / \mathrm{Ti}$ ratios plotted versus $\mathrm{Rb}$ diagrams (Fig. 15A,B), lavas with disequilibrium textures (FDE) fall on the representative mixing curves drawn by using average $\mathrm{F}$ dacites as a silicic end-member and considering two basic ME end-members (E1: average of SC27a, SC35a, and SC49a,b; E2: SC37a andesitic enclave). Shifting of some points from representative mixing curves can be interpreted as previous or coeval plagioclase, amphibole, and pyroxene fractional crystallization, although may also been affected by mineral sorting and/or diffusion processes.

\subsection{Proposed magma mingling/mixing scenario}

Magmatic processes such as differentiation, eruption style, vesiculation, and fluid flow are mainly ruled by chemical composition and inter-related melt physical properties including temperature, density, viscosity, and crystallinity. When two contrasting magmas interact several scenarios may unfold (Donoghue et al., 1995): (a) the melts may mix physically, thereby forming a hybrid magma; (b) one magma may freeze against the host magma, giving a net-vein complex, and abruptly arresting the mixing process; (c) the melts may mix partially but incompletely, particularly when the two end-member components are porphyritic, leaving phenocrysts from both magmas with strong disequilibrium textures; and (d) the melts may intermingle but not mix, forming a banded rock. Where mixing has been efficient, the only evidence for this process may be disequilibrium textures and/or linear arrays in Harker diagrams. However, where mixing is limited or incomplete, the development of magmatic enclaves or banded rocks may occur, which could retain the identity of the end-members. These phenomena have operated commonly in volcanic and plutonic environments (e.g., Nakamura, 1995; Eichelberger et al., 2000; Coombs et al., 2002; Brown et al., 2006; Kumar and Rino, 2006; Dokukina et al., 2010). 
Therefore, the following model is proposed for magma mingling/mixing in Sierra de las Cruces volcanic range, that include the recurrent operation of the (b) and (c) scenarios by Donoghue et al. (1995) from 3.5 to 0.4 Ma. Fix (1975) reported a decrease in the seismic velocities at the base of the crust in the central MVB. Campos-Enríquez and Sánchez-Zamora (2000) have indeed interpreted gravity data to infer the presence of partial melts in the lower crust beneath this region. These magmas might be stored at the base of the crust, transferring heat to shallower crustal levels and provoking their partial melting. SC dacitic rocks were probably generated by partial melting of the upper continental crust (depth at the base $\sim 10 \mathrm{~km}$; Ortega-Gutiérrez et al., 2008), and were subsequently stored in a shallow level magma chamber. The combined Sr-Nd isotope data from the Mexican lower crust and crustal xenoliths from Popocatépetl stratovolcano (Fig. 13) are in general consistent with a significant crustal involvement in the genesis of SC rocks. Sodic plagioclase, Mg-hastingsite amphibole, hypherstene and minor quartz were crystallized prior to the injection of the andesitic magma. Subsequently, a small volume of andesitic magma, probably generated at a deeper crustal level (lower crust (?): $25-45 \mathrm{~km}$; Ortega-Gutiérrez et al., 2008), intruded in the shallow magma chamber, losing heat to the surroundings and starting to vesiculate. Eichelberger et al. (2000) suggested that, if ponding mafic magma operates like a rising piston, co-mingled lavas are slowly expulsed reaching the surface by a volatile-poor and non-explosive effusive eruption. Felsic minerals in the host dacite became round and embayed, plagioclase crystals were sieved, and mafic minerals developed reaction rims as a response to an increase in temperature. On the other hand, quenching of the andesitic magma resulted in discrete enclave development, reflecting an incomplete physical mixing process. Mingling process occurred due to differences in physical properties between the two magmas and the relatively small volume proportion of the intermediate magma. Additionally, limited exchange of xenocrysts (labradorite, edenitic amphibole, and bronzite in dacites, oligoclase and andesine in andesitic enclaves) might have occurred during this entrainment stage.

\section{Conclusions}

This study presents detailed petrography, mineral chemistry, and whole-rock geochemical data for Sierra de las Cruces. Magma mingling/mixing processes have played a significant role in the evolution of this volcanic range. Most dacites display several disequilibrium features that imply the involvement of open system magmatic evolution processes over the 3.6 to 0.4 Ma period. Several mineralogical lines of evidence confirm the interaction between andesitic magmas, probably originated in the interface between upper and lower crust, and felsic magmas possibly derived from upper crust partial melting. These lines of evidence include: (a) chilled magmatic enclaves which probably represent the material that mingled with felsic magma, causing thermal and compositional disequilibrium; (b) presence of more and less silicic amphiboles in the same sample, some of them showing reaction textures and inverse zoning; (c) bronzite and hypersthene orthopyroxenes displaying augitic reaction rims, and (d) sieved plagioclase crystals and their occurrence together with clear normal plagioclase, as well as oscillatory zoning of sieved plagioclase. Magma mixing processes in Sierra de las Cruces are also supported by linear arrays in bivariate plots of major elements. Diagrams based on trace element ratios also point out to an origin by mixing between dacitic and andesitic melts for the Sierra de las Cruces volcanic rocks. Results from this study confirm the significance of magma mixing processes in the intermediate-felsic volcanic rocks petrogenesis in the central MVB.

\section{Acknowledgments}

This study was funded by PAICYT-UANL program (Project CT786-02). Thanks are due to CONACyT and UANL for studentships (PRS, SGMG, and OMRA). We would like to thank Francisco Anguita, José González del Tánago and Alfredo Fernández Larios (Universidad Complutense) for laboratory assistance during microprobe analyses. We are also grateful to María Luisa Osete (Universidad Complutense) for having provided some samples utilized in this paper. The first author (FVT) wishes to express his gratefulness to Academic exchange office - UANL for institutional and financial support. Comments by A. Aparicio, S. Kumar, and an anonymous reviewer significantly improved the manuscript.

\section{References}

Aguirre-Díaz, G.J. (2001): Recurrent magma mingling in successive ignimbrites from Amealco caldera, central Mexico. Bulletin of Volcanology 63, 238-251. doi: 10.1007/s004450100138

Aguirre-Díaz, G.J., Dubois, M., Laureyns, J., Schaaf, P. (2002): Nature and P-T conditions of the crust beneath the central Mexican Volcanic Belt based on a Precambrian crustal xenolith. International Geology Review 44, 222-242. doi: 10.1080/00206810009465073

Alpaslan, M., Ekici, T., Otlu, N., Boztug, D., Temel, A. (2005): Magmatic processes and mixing origin of andesite: Miocene Karamağara volcanics, Central Anatolia, Turkey. Geological Journal 40, 193-214. doi: $10.1002 / g j .1002$

Bacon, C.R. (1986): Magmatic inclusions in silicic and intermediate volcanic rocks. Journal of Geophysical Research 91, 6091-6112. doi: 10.1029/JB091iB06p06091

Bacon, C.R., Hirschmann, M.M. (1988): Mg/Mn partitioning as a test for equilibrium between coexisting Fe-Ti oxides. American Mineralogist 73, 57-61. 
Besch, T., Verma, S.P., Krammer, U., Negendank, J.F.W., Tobschall, H.J. (1995): Assimilation of sialic crustal material by volcanics of the easternmost extension of the Trans-Mexican Volcanic Belt - Evidence from $\mathrm{Sr}$ and $\mathrm{Nd}$ isotopes. Geofisica Internacional 34, 263-281.

Blake, S., Fink, J.H. (2000): On the deformation and freezing of enclaves during magma mixing. Journal of Volcanology and Geothermal Research 95, 1-8. doi: 10.1016/S0377-0273(99)00129-8

Bloomfield, A.L., Arculus, R.J. (1989): Magma mixing in the San Francisco Volcanic Field, AZ. Contributions to Mineralogy and Petrology 102, 429-453. doi: 10.1007/BF00371086

Borg, L.E., Clynne, M.A. (1998): The petrogenesis of felsic calc-alkaline magmas from the Southernmost Cascades, California: Origin by partial melting of Basaltic Lower Crust. Journal of Petrology 39, 1197-1222. doi: 10.1093/petroj/39.6.1197

Brown, B.L., Eichelberger, J.C., Patino, L.C., Vogel, T.A., Uto, K., Hoshizumi, H. (2006): Magma mingling as indicated by texture and $\mathrm{Sr} / \mathrm{Ba}$ ratios of plagioclase phenocrysts from Unzen volcano, SW Japan. Journal of Volcanology and Geothermal Research 154, 103-116. doi: 10.1016/j.jvolgeores.2005.09.022.

Campos-Enríquez, J.O., Sánchez-Zamora, O. (2000): Crustal structure across southern Mexico inferred from gravity data. Journal of South American Earth Sciences 13, 479-489. doi: 10.1016/S08959811(00)00045-6.

Chelsey, J., Ruiz, J., Righter, K., Ferrari, L., Gomez-Tuena, A. (2002): Source contamination versus assimilation: an example from the Trans-Mexican Volcanic Arc. Earth and Planetary Science Letters 195, 211-221. doi: 10.1016/S0012-821X(01)00580-5

Clyne, M. (1999): A complex magma mixing origin for rocks erupted in 1915, Lassen Peak, California. Journal of Petrology 40, 105-132. doi: $10.1093 /$ petroj/40.1.105

Coombs, M.L., Eichelberger, J.C., Rutherford, M.J. (2002): Experimental and textural constraints on mafic enclave formation in volcanic rocks. Journal of Volcanology and Geothermal Research 119, 125 144. doi: 10.1016/S0377-0273(02)00309-8.

De Cserna, Z., Fries, C., Rincón-Orta, C., Silver, T.L., Westley, H., Solorio-Munguía, J., Schmitter-Villada, E. (1974): Datos geocronométricos terciarios de los Estados de México, Morelos y Guerrero. Boletín de la Asociación Mexicana de Geólogos Petroleros 26, 263-273.

Delgado-Granados, H.,Martín del Pozo, A.L. (1993): Pliocene to Holocene volcanic geology at the junction of Las Cruces, Chichinautzin and Ajusco ranges, southwest of Mexico City. Geofísica Internacional 32, 511-522.

Dokukina, K.A., Konilov, A.N., Kaulina, T.V., Vladimirov, V.G. (2010):Interaction between mafic and felsic magmas in subvolcanic environment (Tastau igneous complex, eastern Kazakhstan). Russian Geology and Geophysics 51, 625-643. doi: 10.1016/j. rgg.2010.05.004

Donoghue, S.L., Gamble, J.A., Palmer, A.S., Stewart, R.B. (1995): Magma mingling in an andesite pyroclastic flow of the Pourahu Member, Ruapehu volcano, New Zealand. Journal of Volcanology and Geothermal Research 68, 177-191. doi: 10.1016/0377-0273(95)00012-J

Droop, G.T.R. (1987): A general equation for estimating $\mathrm{Fe}^{+3}$ concentrations in ferromagnesian silicates and oxides from microprobe analyses, using stochiometric criteria. Mineralogical Magazine 51, 431435.

Eichelberger, J.C. (1980): Vesiculation of mafic magma during replenishment of silicic magma chambers. Nature 288, 446-450. doi: $10.1038 / 288446 \mathrm{a} 0$

Eichelberger, J.C., Chertkoff, D.G., Dreher, S.T., Nye, C.J. (2000): Magmas in collision: Rethinking chemical zonation in silicic magmas. Geology 28, 603-608. doi:10.1130/0091-7613(2000)28<603:MICRCZ> 2.0.CO;2

Eichelberger, J.C., Izbekov, P.E., Browne, B.L. (2006): Bulk chemical trends at arc volcanoes are not liquid lines of descent. Lithos 87, 135-
154. doi: 10.1016/j.lithos.2005.05.006

Faure, G. (1986): Principles of Isotope Geology. Wiley, New York: 608 p.

Ferrari, L. (2004): Slab detachment control on mafic volcanic pulse and mantle heterogeneity in central Mexico. Geology 32, 77-80. doi:10.1130/G19887.1

Ferrari, L., López-Martínez, M., Aguirre-Díaz, G., Carrasco-Nuñez, G. (1999):Space-time patterns of Cenozoic arc volcanism in central Mexico: from the Sierra Madre Occidental to the Mexican Volcanic Belt. Geology, 27: 303-306. doi: 10.1130/0091-7613(1999)027<0303: STPOCA > 2.3.CO;2

Fix, J.E. (1975): The crust and the upper mantle of central Mexico. Geophysical Journal of the Royal Astronomical Society 43, 453-499. doi: 10.1111/j.1365-246X.1975.tb00643.x

Fries, C. (1960): Geología de Estado de Morelos y partes adyacentes de México y Guerrero, región central meridional de México. Boletín del Instituto de Geología UNAM 60, 236.

García-Palomo, A., Macías, J.L., Arce, J.L., Capra, L., Garduño, V.H.,Espíndola, J.M. (2002): Geology of Nevado de Toluca volcano and surrounding areas, central Mexico. Geological Society of America, Map and Chart Series MCH089, 1-48.

García-Palomo, A., Zamorano, J.J., López-Miguel, C., Galván-García, A., Carlos-Valerio, V., Ortega, R., Macías, J.L. (2008): El arreglo morfoestructural de la Sierra de las Cruces, México central. Revista Mexicana de Ciencias Geológicas 25, 158-178.

Gençalioğlu Kuşcu, G., Floyd, P.A. (2001): Mineral compositional and textural evidence for magma mingling in the Saraykent volcanics. Lithos 56, 207-230. doi: 10.1016/S0024-4937(00)00051-7

Gómez-Tuena, A., Capra, L., Cai, Y., Goldstein, S.L., Langmuir, C.H. (2006): Geochemical evidence for melting of a complete section of the subducted slab at Nevado de Toluca Volcano, Central Mexico. Geophyscal Research Abstracts, European Geosciences Union, General Assembly, Vienna: p. 03051.

Gómez-Tuena, A., Orozco-Esquivel, T., Ferrari, L. (2007): Igneous petrogenesis of the Trans-Mexican Volcanic Belt. In: S.A. Alaniz-Álvarez, A.F. Nieto-Samaniego (eds.), Geology of Mexico: Celebrating the Centenary of the Geological Society of Mexico. Geological Society of America Special Paper 442, Geological Society of America, Boulder: 129-181. doi: 10.1130/2007.2422(05)

Hammarstrom, J.M., Zen, E. (1986): Aluminum in hornblende: an empirical igneous geobarometer. American Mineralogist 71, 1297-1313.

Haskin, L.A., Haskin, M.A., Frey, F.A., Wilderman, T.R. (1968): Relative and absolute terrestrial abundances of the rare-earths. In: L.H. Ahrens (ed.), Origin and distribution of the elements. Pergamon Press, London: 889-912.

Jarosewich, E., Nelen, J.A., Norberg, J.A. (1980): Reference samples for electron microprobe analysis. Geostandards Newsletter 4, 43-47. doi: 10.1111/j.1751-908X.1980.tb00273.x

Kroll, H., Bambauer, H.-U. (1981): Diffusive and displacive transformation in plagioclase and ternary feldspar series. American Mineralogist 66, 763-769.

Kumar, S., Rino, V. (2006): Mineralogy and geochemistry of microgranular enclaves in Palaeoproterozoic Malanjkhand granitoids, central India: evidence of magma mixing, mingling, and chemical equilibration. Contributions to Mineralogy and Petrology 152, 591-609. doi: 10.1007/s00410-006-0122-3

Kumar, S., Pieru, T. (2010): Petrography and major elements geochemistry of microgranular enclaves and Neoproterozoic granitoids of South Khasi, Meghalaya: Evidence of magma mixing and alkali diffusion. Journal of the Geological Society of India 76, 345-360. doi: 10.1007/s12594-010-0106-9

Leake, B.E., Wolley, A.R., Arps, C.E.S., Birch, W.D., Gilbert, M.C., Grice, J.D., Hawthorne, F.C., Kato, A., Kisch, H.J., Krivovichev, V.G., Linhthout, K., Laird, J., Mandaring, J.A., Maresch, W.V., Nick- 
el, E.H., Rock, N.M.S., Schumacher, J.C., Smith, D.C., Stephenson, N.C.N., Ungaretti, L., Whittaker, E.J.W., Youzhi, G. (1997): Nomenclature of amphiboles: report of the subcommittee on amphiboles of the International Mineralogical Association, commission on new minerals and mineral names. Canadian Mineralogist 35, 219-246.

LeBas, M.J. (1989): Nephelinitic and basanitic rocks. Journal of Petrology 30, 1299-1312. doi: 10.1093/petrology/30.5.1299

LeBas, M.J., LeMaitre, R.W., Streckeisen, A., Zanettin, B. (1986): A chemical classification of volcanic rocks based on the total alkali-silica diagram. Journal of Petrology 27, 745-750. doi:10.1093/petrology/27.3.745

Luhr, J.F. (1997): Extensional tectonics and the diverse primitive volcanic rocks in the western Mexican Volcanic Belt. Canadian Mineralogist 35, 473-500.

Luhr, J.F., Carmichael, I.S.E. (1980): The Colima volcanic complex, Mexico: I. Post-caldera andesites from volcano Colima. Contributions to Mineralogy and Petrology 71, 343-372. doi: 10.1007/BF00374707

Márquez, A., De Ignacio, C. (2002): Mineralogical and geochemical constraints for the origin and evolution of magmas in Sierra de Chichinautzin, Central Mexican Volcanic Belt. Lithos 62, 35-62. doi: 10.1016/S0024-4937(02)00069-5

Márquez, A., Oyarzun, R., Doblas, M., Verma, S.P. (1999a): Alkalic (OIB-type) and calc-alkalic volcanism in the Mexican Volcanic Belt: a case for plume-related magmatism and propagating rifting at an active margin? Geology 27, 51-54. doi:10.1130/00917613(1999)027<0051:AOIBTA>2.3.CO;2

Márquez, A., Verma, S.P., Anguita, F., Oyarzun, R., Brandle, J.L. (1999b): Tectonics and volcanism of Sierra Chichinautzin: extensión at the front of the central Trans-Mexican Volcanic Belt. Journal of Volcanology and Geothermal Research 93, 125-150. doi: 10.1016/ S0377-0273(99)00085-2

Middllemost, E.A.K. (1989): Iron oxidation ratios, norms and the classification of volcanic rocks. Chemical Geology 77, 19-26. doi: 10.1016/0009-254(89)90011-9

Mooser, F., Nairn, A.E.M., Negendank, J.F.W. (1974): Paleomagnetic investigations of the Tertiary and Quaternary igneous rocks: VIII. A paleomagnetic and petrologic study of volcanics of Valley of Mexico. Geologische Rundschau 63, 451-483. doi: 10.1007/BF01820824

Mora-Alvarez, G., Caballero, C., Urrutia-Fucugauchi, J., Uchiumi, S. (1991): Southward migration of volcanic activity in the Sierra de las Cruces, basin of México? A preliminary K-Ar dating and paleomagnetic study. Geofisica Internacional 30, 61-70.

Morán-Zenteno, D.J., Alba-Aldave, L.A., Martínez-Serrano, R.G., Reyes-Salas, M.A., Corona-Esquivel, R., Ángeles-García, S. (1998): Stratigraphy, geochemistry and tectonic significance of the Tertiary volcanic sequence of the Taxco-Tilzapotla region, southern Mexico. Revista Mexicana de Ciencias Geológicas 15, 167-180.

Nakada, S. (1991): Magmatic processes in titanite-bearing dacites, central Andes of Chile and Bolivia. American Mineralogist 76, 548-560.

Nakamura, M. (1995): Continuous mixing of crystal mush and replenished magma in the ongoing Unzen eruptions. Geology 23, 807-810. doi: 10.1130/0091 - 7613(1995)023 < 0807: CMOCMA > 2.3.CO;2

Nakamura, N. (1974): Determination of REE, Ba, Mg, Na, and K in carbonaceous and ordinary chondrites. Geochimica et Cosmochimica Acta 38, 757-775. doi: 10.1016/0016-7037(74)90149-5

Nixon, G.T. (1988a): Petrology of the younger andesites and dacites of Iztaccíhuatl volcano, Mexico: I. Disequilibrium phenocryst assemblages as indicators of magma chamber processes. Journal of Petrology 29, 213-264. doi:10.1093/petrology/29.2.213

Nixon, G.T. (1988b): Petrology of the younger andesites and dacites of Iztaccíhuatl volcano, Mexico: II. Chemical stratigraphy, magma mixing, and the composition of basaltic magma influx. Journal of Petrology 29, 265-303. doi:10.1093/petrology/29.2.265

Nixon, G.T., Pearce, T.H. (1987): Laser-interferometry study of oscilla- tory zoning in plagioclase: the record of magma mixing and phenocryst recycling in calc-alkaline magma chambers, Iztaccíhuatl volcano, Mexico. American Mineralogist 72, 1144-1162.

Ortega-Gutiérrez, F., Elías-Herrera, M., Dávalos-Elizondo, M.G. (2008): On the nature and role of the lower crust in the volcanic front of theTrans-Mexican Volcanic Belt and its fore-arc region, southern and central Mexico. Revista Mexicana de Ciencias Geológicas 25, 346-364.

Osete, M.J., Ruiz-Martínez, V.-C., Caballero, C., Galindo, C., UrrutiaFucugauchi, J., Tarling, D.H. (2000): Southward migration of continental volcanic activity in the Sierra de Las Cruces, Mexico: paleomagnetic and radiometric evidence. Tectonophysics 318, 201-215. doi: 10.1016/S0040-1951(99)00312-1

Owny, S.E., Lange, R.A., Hall, C.M., Delgado-Granados, H. (2011): Origin of andesite in the deep crust and eruption rates in the TancítaroNueva Italia region of the central Mexican arc. Geological Society of America Bulletin 123, 274-294. doi:10.1130/B30124.1

Pardo, M., Suárez, G. (1995): Shape of the subducted Rivera and Cocos plates in southern Mexico: Seismic and tectonic implications. Journal of Geophysical Research 100, 12357-12373. doi: 10.1029/95JB00919

Patchett, P.J., Ruiz, J. (1987): Nd isotopic ages of crustal formation and metamorphism in the Precambrian of eastern and southern Mexico. Contributions to Mineralogy and Petrology 96, 523-528. doi: 10.1007/BF01166697

Roberts, S.J., Ruiz, J. (1989): Geochemistry of exposed granulite facies terrains and lower crustal xenoliths in Mexico. Journal of Geophysical Research 94, 7961-7974. doi: 10.1029/JB094iB06p07961

Rollinson, H.R. (1993): Using of geochemical data: evaluation, presentation, interpretation. Longman Scientific \& Technical, New York: $352 \mathrm{p}$.

Rudnick, R.L., Gao, S. (2003): Volume 3 Composition of Continental Crust. In: H.D. Holland, K.K. Turekian (eds.), Treatise on Geochemistry, Elsevier, Amsterdam: p. 1-64. doi: 10.1016/B0-08-0437516/03016-4

Ruiz, J., Patchett, P.J., Arculus, R.J. (1988a): Nd-Sr isotope composition of lower crustal xenoliths - evidence for the origin of mid-Tertiary felsic volcanics in Mexico. Contributions to Mineralogy and Petrology 99, 36-43. doi: 10.1007/BF00399363

Ruiz, J., Patchett, P.J., Ortega-Gutierrez, F. (1988b): Proterozoic and Phanerozoic basement terranes of Mexico from $\mathrm{Nd}$ isotopic studies. Geological Society of America Bulletin 100, 274-281. doi:10.1130/0016-7606(1988)100<0274:PAPBTO > 2.3.CO;2

Sakuyama, M. (1981): Petrological study of the Myoko and Kurohime Volcanoes, Japan: crystallization sequence and evidence of magma mixing. Journal of Petrology 22, 553-583. doi:10.1093/petrology/22.4.553

Sánchez-Rubio, G. (1984): Cenozoic volcanism in the Toluca-Amealco region, central Mexico. Ph.D. thesis, University of London, London: $145 \mathrm{p}$.

Schaaf, P., Heinrich, W., Besch, T. (1994): Composition and Sm-Nd isotopic data of the lower crust beneath San Luis Potosí, central Mexico: evidence from granulite-facies xenolith suite. Chemical Geology 118, 63-84. doi: 10.1016/0009-2541(94)90170-8

Schaaf, P., Stimac, J., Siebe, C., Macías, J.L. (2005): Geochemical evidence for mantle origin and crustal processes in volcanic rocks from Popocatépetl and surrounding monogenetic volcanoes, Central Mexico. Journal of Petrology 46, 1243-1282. doi:10.1093/petrology/ egi015

Schlaepfer, C. (1968): Hoja México 14Q-h(5), con resumen de la hoja México, Distrito Federal y Estados de México y Morelos. Carta Geológica de México E. 1:100.000, Instituto de Geología, UNAM, México.

Seto, M., Akagi, T. (2008): Chemical condition for the appearance of a negative $\mathrm{Ce}$ anomaly in stream waters and groundwaters. Geochemi- 
cal Journal 42, 371-380.

Shelley, D. (1993): Igneous and metamorphic rocks under the microscope. Chapman and Hall, London: 445 p.

Sheth, H.C., Torres-Alvarado, I.S., Verma, S.P. (2000): Beyond subduction and plumes: a unified tectonic-petrogenetic model for the Mexican Volcanic Belt. International Geology Review 42, 1116-1132. doi: $10.1080 / 00206810009465129$

Sosa-Ceballos, G., Gardner, J.E., Siebe, C., Macías, J.L. (2012): A caldera-forming eruption $\sim 14,100{ }^{14} \mathrm{C}$ yr BP at Popocatépetl volcano, Mexico: Insights from eruption dynamics and magma mixing. Journal of Volcanology and Geothermal Research 213-214, 27-40. doi: 10.1016/j.jvolgeores.2011.11.001

Sparks, R.S.J., Marshall, L.A. (1986): Thermal and mechanical constraints on mixing between mafic and silicic magmas. Journal of Volcanology and Geothermal Research 29, 99-124. doi: 10.1016/03770273(86)90041-7

Stimac, J.A., Pearce, T.H., Donnely-Nolan, J.M., Hearn, J.R.B.C. (1990): The origin and implications of undercooled andesitic inclusions in rhyolites, Clear Lake Volcanics, California. Journal of Geophysical Research 95, 17729-17746. doi: 10.1029/JB095iB11p17729

Stormer, J.C., Jr. (1983): The effects of recalculation on estimates of temperature and oxygen fugacity from analyses of multicomponent iron-titanium oxides. American Mineralogist 68, 586-594.

Straub, S.M., Martin-Del Pozzo, A.L. (2001): The significance of phenocryst diversity in tephra from recent eruptions at Popocatepetl volcano (central Mexico). Contributions to Mineralogy and Petrology 140, 487-510. doi: 10.1007/PL00007675

Sun, S.-S., McDonough, W.F. (1989): Chemical and isotopic systematics of oceanic basalts: implications for mantle composition and processes. In: A.D. Saunders, M.J. Norry (eds.), Magmatism in the ocean basins. Geological Society of America Special Publication 42, Geological Society of America, Boulder, p. 313-345.

Tsuchiyama, A. (1985): Dissolution kinetics of plagioclase in the melt of the system diopside-albite-anorthite, and origin of dusty plagioclase in andesites. Contributions to Mineralogy and Petrology 89, 1-16. doi: 10.1007/BF01177585

Urrutia-Fucugauchi, J., Uribe-Cifuentes, R.M. (1999): Lower-crustal xenoliths form the Valle de Santiago maar field, Michoacán Guanajuato volcanic field, central Mexico. International Geology Review 41, 1067-1081. doi: 10.1080/00206819909465192

Vázquez-Sánchez, E., Jaimes-Palomera, L.R. (1989): Geología de la Cuenca de México. Geofísica Internacional 28, 133-189.

Velasco-Tapia, F., Verma, S.P. (2001a): Estudios geológicos y geoquímicas en la Sierra de Chichinautzin, Cinturón Volcánico Mexicano. Revista Mexicana de Ciencias Geológicas 18, 1-36.

Velasco-Tapia, F., Verma, S.P. (2001b): First partial melting inversion model for a rift-related origin of Sierra de Chichinautzin Volcanic Field, Central Mexican Volcanic Belt. International Geology Review 43, 788-817. doi: 10.1080/00206810109465048

Velasco-Tapia, F., Verma, S.P. (2013): Magmatic processes at the front of Central Mexican Volcanic Belt: Sierra de Chichinautzin Volcanic Field (Mexico). Turkish Journal of Earth Sciences 22, 32-60. doi: 10.3906/yer-1104-9.

Verma, S.P. (1999): Geochemistry of evolved magmas and their relationship to subduction-unrelated mafic volcanism at the volcanic front of the central Mexican Volcanic Belt. Journal of Volcanology and Ge- othermal Research 93, 151-171. doi: 10.1016/S0377-0273(99)0086-4 Verma, S.P. (2000): Geochemistry of the subducting Cocos plate in the origin of subduction-unrelated mafic volcanism at the volcanic front of the central Mexican Volcanic Belt. In: H. Delgado-Granados, G.J. Aguirre-Díaz, J.M. Stock (eds.), Cenozoic tectonics and volcanism of Mexico. Geological Society of America Special Paper 334, Geological Society of America, Boulder: 195-222.

Verma, S.P. (2002): Absence of Cocos plate subduction-related basic volcanism in southern Mexico: a unique case on earth? Geology 30, 1095-1098. doi: 10.1130/0091-7613(2002)030<1095:AOCPSR $>2.0$. $\mathrm{CO} ; 2$

Verma, S.P. (2009): Continental rift setting for the central part of the Mexican Volcanic Belt: A statistical approach. Open Geology Journal 3, 8-29. doi: 10.2174/1874262900903010008

Verma, S.P., Torres-Alvarado, I.S., Zotelo-Rodríguez, Z.T. (2002): SINCLAS: Standard Igneous Norm and Volcanic Rock Classification System. Computers \& Geosciences 28, 711-715. doi: 10.1016/S00983004(01)00087-5

Verma, S.P., Torres-Alvarado, I.S., Velasco-Tapia, F. (2003): A revised CIPW norm. Schweizerische Mineralogische und Petrographische Mitteilungen 83, 197-216. doi: 10.5169/seals-63145

Verma, S.P., Pandarinath, K., Velasco-Tapia, F., Rodríguez-Ríos, R. (2009): Evaluation of odd-even effects in limits of detection for electron microprobe analysis of natural minerals. Analytica Chimica Acta 638, 126-132. doi:10.1016/j.aca.2009.02.022

Weiss, D., Kieffer, B., Maerschalk, C., Barling, J., de Jong, J., Williams, G.A., Hanano, D., Pretorius, W., Matielli, N., Scoates, J.S., Goolaerts, A., Friedman, R.M., Mahoney, J.B. (2006): High-precision isotopic characterization of USGS reference materials by TIMS and MC-ICP-MS. Geochemistry Geophysics Geosystems 7, Q08006. doi: 10.1029/2006GC001283.

Vernon, R.H., Etheridge, M.E., Wall, V.J. (1988): Shape and microstructure of microgranitoid enclaves: indicators of magma mingling and flow. Lithos 22, 1-11. doi: 10.1016/0024-4937(88)90024-2

Viswanathan, K. (1971): A new X-ray method to determine the anorthite content and structural state of plagioclases. Contributions to Mineralogy and Petrology 30, 332-335. doi: 10.1007/BF00404727

Wallace, P.J., Carmichael, I.S.E. (1994): Petrology of Volcán Tequila, Jalisco, Mexico: disequilibrium phenocryst assemblages and evolution of the subvolcanic magma system. Contributions to Mineralogy and Petrology 117, 345-361. doi: 10.1007/BF00307270

Wallace, P.J., Carmichael, I.S.E. (1999): Quaternary volcanism near the Valley of Mexico: implications for subduction zone magmatism and the effects of crustal thickness variations on primitive magma compositions. Contributions to Mineralogy and Petrology 135, 291-314. doi: 10.1007/s004100050513

Witter, J.B., Kress, V.C., Newhall, C.G. (2005): Volcán Popocatépetl, Mexico. Petrology, magma mixing, and immediate sources of volatiles for the 1994-present eruption. Journal of Petrology 46, 2337 2366. doi:10.1093/petrology/egi058

Yavuz, F. (1999): A revised program for microprobe-derived amphibole analyses using the IMA rules. Computers \& Geosciences 25, 909-927. doi: 10.1016/S0098-3004(99)00055-2

Zindler, A., Hart, S. (1986): Chemical geodynamics. Annual Review of Earth and Planetary Science 14, 493 -571. doi: 10.1146/annurev. ea.14.050186.002425

\section{Appendix A - Supplementary material}

Tables 1 to 10 cited in this paper can be downloaded from http://revistas.ucm.es/index.php/JIGE/ 